\title{
The Effect of Aspergillus Thermomutatus Chrysovirus 1 on the Biology of Three Aspergillus Species
}

\author{
Mahjoub A. Ejmal ${ }^{1}$, David J. Holland ${ }^{2}$, Robin M. MacDiarmid 1,3@ and Michael N. Pearson 1,* \\ 1 School of Biological Sciences, the University of Auckland, Auckland 1142, New Zealand; \\ mejm158@aucklanduni.ac.nz (M.A.E.); robin.macdiarmid@plantandfood.co.nz (R.M.M.) \\ 2 Infectious Diseases Unit, Division of Medicine, Middlemore Hospital, Auckland 1640, New Zealand; \\ David.Holland@middlemore.co.nz \\ 3 Plant and Food Research, Auckland 1142, New Zealand \\ * Correspondence: m.pearson@auckland.ac.nz
}

Received: 4 September 2018; Accepted: 29 September 2018; Published: 2 October 2018

\begin{abstract}
This study determined the effects of Aspergillus thermomutatus chrysovirus 1 (AthCV1), isolated from Aspergillus thermomutatus, on A. fumigatus, A. nidulans and A. niger. Protoplasts of virus-free isolates of $A$. fumigatus, $A$. nidulans and $A$. niger were transfected with purified AthCV1 particles and the phenotype, growth and sporulation of the isogenic AthCV1-free and AthCV1-infected lines assessed at $20^{\circ} \mathrm{C}$ and $37^{\circ} \mathrm{C}$ and gene expression data collected at $37^{\circ} \mathrm{C}$. AthCV1-free and AthCV1-infected A. fumigatus produced only conidia at both temperatures but more than ten-fold reduced compared to the AthCV1-infected line. Conidiation was also significantly reduced in infected lines of $A$. nidulans and $A$. niger at $37^{\circ} \mathrm{C}$. AthCV1-infected lines of $A$. thermomutatus and $A$. nidulans produced large numbers of ascospores at both temperatures, whereas the AthCV1-free line of the former did not produce ascospores. AthCV1-infected lines of all species developed sectoring phenotypes with sclerotia produced in aconidial sectors of A. niger at $37{ }^{\circ} \mathrm{C}$. AthCV1 was detected in $18 \%$ of sclerotia produced by AthCV1-infected A. niger and $31 \%$ of ascospores from AthCV1-infected A. nidulans. Transcriptome analysis of the naturally AthCV1-infected A. thermomutatus and the three AthCV1-transfected Aspergillus species showed altered gene expression as a result of AthCV1-infection. The results demonstrate that AthCV1 can infect a range of Aspergillus species resulting in reduced sporulation, a potentially useful attribute for a biological control agent.
\end{abstract}

Keywords: chrysovirus; mycovirus; Aspergillus; A. fumigatus; A. nidulans; A. niger; A. thermomutatus; biocontrol

\section{Introduction}

Mycoviruses have been reported in a wide variety of fungi [1]. In nature, mycoviruses may be vertically transmitted through both asexual and sexual spores, although the rate of transmission varies depending upon the fungal species, the virus and the growth conditions [2]. Horizontal transmission is typically via hyphal anastomosis which is often limited by hyphal incompatibility, even within a species [3], so consequently most mycoviruses have a narrow natural host range. However, there is growing evidence that extracellular transmission may occur [4-6] potentially providing a mechanism for inter-species transmission, although to date this has only been demonstrated in a few instances [4-6].

While the vast majority of mycoviruses appear to have little or no obvious impact on their host, there are reports of significant changes in the phenotype and growth characteristics of some fungi due to viral infection. These alterations include reduction in growth and virulence of plant pathogenic fungi [7-11], cytological alterations of cellular organelles [12], changes in pigmentation [13] 
and enzymatic activities [14], enabling the host fungus to confer heat tolerance to its host plant [15] and production of killer toxins [16,17]. Moreover, dsRNAs of viral origin are known to be interferon inducers [18].

Like many mycoviruses, most chrysoviruses are associated with latent infections of their fungal hosts [19]. However, there are reports of negative impacts on the fungal host attributed to chrysovirus infection, including: attenuated growth, hypovirulence and sector formation caused by Botryosphaeria dothidea chrysovirus 1 [20]; weakened growth, altered pigmentation and abnormal hyphal aggregation induced by Magnaporthe oryzae chrysovirus 1-A [21]; the absence of aerial hyphae formation and subsequent conidiophore development with impaired mycelial growth and albino hyphae produced due to Magnaporthe oryzae chrysovirus 1-B infection [22]; hypovirulence of the host fungal strain caused by Botryosphaeria dothidea chrysovirus 1 [23]; aconidial sectoring, decreased pigmentation and reduced biomass induced by Aspergillus fumigatus chrysovirus [24]; and aconidial sectoring, low spore production and reduced radial growth caused by $A$. niger chrysovirus [25].

The effects of mycovirus infection on gene expression have been studied for some fungi. In a study of four different Fusarium graminearum viruses [26] a hypovirus (FgV1), a chrysovirus (FgV2), a totivirus (FgV3) and a partitivirus (FgV4) were individually used to infect Fusarium graminearum strain $\mathrm{PH}-1$ via protoplast fusion. An RNA-Seq-based transcriptome analysis of each of the virus-infected PH-1 cultures showed that all four mycoviruses affected the transcriptome profiles and each mycovirus regulated the expression of a totally different set of host genes. However, transcriptome profiles of the naturally infected Fusarium graminearum strains do not appear to have been included in that assessment. Also, Sun et al. [27] showed that levels of Mycoreovirus 1-Cp9B21 genomic dsRNA increased when the virus was co-infecting Cryphonectria parasitica together with the Cryphonectria hypovirus 1-EP713.

We previously reported [28] sector formation, with noticeable changes in colony texture and color, plus changes in sporulation rate in cultures of $A$. thermomutatus (isolate Ath-1) infected with Aspergillus thermomutatus chrysovirus 1 (AthCV1). This paper presents the results of a subsequent study to investigate the ability of AthCV1 to infect other Aspergillus species (A. fumigatus, A. niger and A. nidulans) and the biological and molecular impacts of AthCV1 on these species.

\section{Materials and Methods}

\subsection{Source of Aspergillus Isolates}

An isolate of A. thermomutatus infected with AthCV1 was used as a source of virus particles for protoplast transfection of A. fumigatus (Afu-13, dsRNA-free), A. niger (Ang-9, dsRNA-free) and A. nidulans (And-1, dsRNA-free). Clinical isolates of Afu-13 and Ang-9 were provided by Dr David Holland, Clinical Director Infection Services, Middlemore Hospital, Auckland, New Zealand and And-1 was provided by Wendy McKinney, Mycology Reference Laboratory, Auckland Hospital. Cultures were maintained on Potato Dextrose Agar (PDA, DifcoTM, BD Diagnostics, Heidelberg, Germany) in the dark at $37^{\circ} \mathrm{C}$ and $20^{\circ} \mathrm{C}$.

\subsection{Virus Purification and Detection}

AthCV1 was purified as follows: Virus-infected A. thermomutatus was grown in Yeast Extract Peptone Dextrose broth (YPD Broth, Yeast Extract $5 \mathrm{~g} / \mathrm{L}$, Microbiological peptone $3 \mathrm{~g} / \mathrm{L}$ and Dextrose $10 \mathrm{~g} / \mathrm{L}$ ) and incubated on a shaking incubator at $180 \mathrm{rpm}$ in the dark for 2 days. Approximately $10 \mathrm{~g}$ of fungal mycelium was harvested on a filter paper using vacuum filtration, ground to a fine powder in liquid nitrogen and transferred to a $50 \mathrm{~mL}$ Falcon tube containing $20 \mathrm{~mL}$ of sodium phosphate buffer (SPB) (0.1 M, pH 7.0) and $10 \mathrm{~mL}$ chloroform. The mixture was incubated for $30 \mathrm{~min}$ on ice on an orbital shaker, at $230 \mathrm{rpm}$ and then centrifuged at $10,000 \times \mathrm{g}$ for $30 \mathrm{~min}$ at $4{ }^{\circ} \mathrm{C}$. The upper aqueous phase was centrifuged at $120,000 \times g$ for $2 \mathrm{~h}$ at $4{ }^{\circ} \mathrm{C}$ and the resultant pellet was re-suspended in $1 \mathrm{~mL} \mathrm{SPB}(0.02 \mathrm{M}$ $\mathrm{pH} 7.0$ ) for $4 \mathrm{~h}$ at $4{ }^{\circ} \mathrm{C}$. The suspension was clarified by centrifugation at $10,000 \times \mathrm{g}$ for $20 \mathrm{~min}$ at $4{ }^{\circ} \mathrm{C}$, the supernatant centrifuged at $120,000 \times g$ for $2 \mathrm{~h}$ at $4{ }^{\circ} \mathrm{C}$ and the pellet was re-suspended in $0.5 \mathrm{~mL}$ 
SPB (0.02 M, pH 7.0) overnight at $4^{\circ} \mathrm{C}$. Following centrifugation at $10,000 \times g$ for 20 min a $50-\mu \mathrm{L}$ drop of the supernatant was negatively stained with $2 \%$ uranyl acetate $(\mathrm{pH} 4.0)$ and observed for virus particles using a Phillips CM12 TEM. The virus was detected by virus-specific reverse transcription polymerase chain reaction (RT-PCR), using virus specific primers that amplified a 639 bp product from the coat protein (genome segment 2), as described by Ejmal et al. [28].

\subsection{Protoplast Preparation and Virus Transfection}

Protoplast preparation and virus transfection were undertaken as described by Ejmal et al. [28]. Briefly, $5 \mathrm{~g}$ of one-day old mycelium, grown in YPD Broth, was washed once with sterile distilled water and once with protoplast buffer $\left(0.8 \mathrm{M} \mathrm{MgSO}_{4} \cdot 7 \mathrm{H}_{2} \mathrm{O}, 0.2 \mathrm{M} \mathrm{C}_{6} \mathrm{H}_{5} \mathrm{Na}_{3} \mathrm{O}_{7} \cdot 2 \mathrm{H}_{2} \mathrm{O}\right.$, pH 5.5). The mycelium was then coarsely chopped and transferred to a flask containing $17 \mathrm{~mL}$ protoplast buffer. Three $\mathrm{mL}$ of filter sterilized Novozyme buffer (1 M Sorbitol, 50 mM Sodium citrate, pH 5.8) containing $200 \mathrm{mg}$ of Lysing Enzymes from Trichoderma harzianum (Sigma-Aldrich, St. Louis, MO, USA) was added to the mycelial suspension, which was incubated for $4 \mathrm{~h}$ at $28^{\circ} \mathrm{C}$ in a shaker at $85 \mathrm{rpm}$. Protoplasts were passed through a $75-\mu \mathrm{m}$ strainer and collected in a 50-mL tube containing $30 \mathrm{~mL} \mathrm{KC} \mathrm{buffer}(0.6 \mathrm{M} \mathrm{KCl}$ and $50 \mathrm{mM} \mathrm{CaCl}_{2}$ ) and centrifuged at $4000 \times \mathrm{g}$ for $10 \mathrm{~min}$. The protoplast pellet was then washed twice with $10 \mathrm{~mL}$ sorbitol-Tris-calcium chloride (STC) buffer (1M Sorbitol, $50 \mathrm{mM}$ Tris, pH 8 and $50 \mathrm{mM}$ $\mathrm{CaCl}_{2} \cdot 2 \mathrm{H}_{2} \mathrm{O}$ ) and centrifuged at $4000 \times \mathrm{g}$ for $10 \mathrm{~min}$ before being was re-suspended in $0.5 \mathrm{~mL} \mathrm{STC}$ and kept on ice. For transfection, $130 \mu \mathrm{L}$ PEG 4000 (60\% in sterile water) was mixed with $70 \mu \mathrm{L}$ potassium chloride-Tris-Calcium Chloride (KTC) buffer (1.8 M KCl, $150 \mathrm{mM}$ Tris pH 8, $150 \mathrm{mM} \mathrm{CaCl} 2$ ) and added to a tube containing $200 \mu \mathrm{L}$ of purified virus particle suspension and $5 \mu \mathrm{L} 0.05 \mathrm{mM}$ spermidine (Sigma-Aldrich, St. Louis, MO, USA). A 200- $\mu$ L aliquot of the protoplast suspension was then added to the suspension and mixed by twirling the tube for $10 \mathrm{~s}$ before it was incubated on ice for $30 \mathrm{~min}$. Following incubation, a mix of $200 \mu \mathrm{L}$ of polyethylene glycol (PEG) 4000 and $100 \mu \mathrm{L}$ KTC was added to the previous suspension and gently twirled again. Following incubation at room temperature for $20 \mathrm{~min}, 40-\mu \mathrm{L}$ aliquots of the mixture were added to $5 \mathrm{~mL}$ warm agar medium (Stabilized Minimal Medium (SMM) containing 0.7\% agar), gently mixed and spread on SMM plates, which were parafilm sealed and incubated at $37^{\circ} \mathrm{C}$. Individual colonies were picked off, grown on fresh PDA plates and sub-cultured three times, at weekly intervals, then checked for the presence of the virus by RT-PCR as described by Ejmal et al. [28]. As negative controls, three plates were spread with a protoplast suspension lacking virus particles, to test protoplast viability. In addition, three plates were spread with no protoplasts in the transfection suspension to test for possible mycelial contamination in the virus particle suspension. As a general contamination check, three plates containing only SMM media were included.

\subsection{Quantifying the Biological Impacts of AthCV1 Infection on Three Aspergillus Species}

Sporulation rate comparisons were conducted at $20^{\circ} \mathrm{C}$ to represent environmental temperature and $37^{\circ} \mathrm{C}$ to represent human body temperature. Five virus-free and five virus-infected lines were grown from single spores, inoculated at the edge of PDA plates ( $9 \mathrm{~cm}$ diameter) and incubated in the dark until the mycelium reached the opposite side of the plate. To harvest conidiospores, the plates were washed with $40 \mathrm{~mL}$ aqueous $0.05 \%$ Tween 80 , which was then filtered through cheesecloth and centrifuged at $8000 \times g$ for $10 \mathrm{~min}$. The spores were re-suspended in $10 \mathrm{~mL}$ distilled water before being counted in a Neubauer chamber, as described by Aneja [29].

For linear growth comparison, five replicates of isogenic virus-free and virus-infected single spore isolates were individually inoculated at the edge of PDA plates and grown at $37{ }^{\circ} \mathrm{C}$ and at $20^{\circ} \mathrm{C}$. The growth was measured every $24 \mathrm{~h}$ until the mycelium reached the far edge of the plate. At the completion of each experiment cultures were tested for the presence of the virus using RT-PCR as described by Ejmal et al. [28].

To compare biomass production five isogenic virus-free and virus-infected single spore isolates, of each species, were grown at $37^{\circ} \mathrm{C}$ and at $20^{\circ} \mathrm{C}$ in the dark. Plugs of the resultant mycelium were 
individually transferred to conical flasks containing $200 \mathrm{~mL}$ YPD Broth and incubated with shaking at $180 \mathrm{rpm}$, in the dark. The resultant mycelium was vacuum filtered and $100 \mathrm{mg}$ of each sample retained for virus screening by one-step RT-PCR by Ejmal et al. [28]. The remainder was dried at $90{ }^{\circ} \mathrm{C}$ for $72 \mathrm{~h}$ before weighing. Data were analyzed by an independent samples $t$-test, using SPSS version 21 (IBM SPSS statistics, Armonk, NY, USA).

\subsection{AthCV1 Transmission Through Ascospores and Sclerotia}

AthCV1 transmission through $A$. nidulans ascospores was tested as follows: First ascospores were processed to eliminate contamination from mycelium and conidia, based on the methods of O'Gorman et al. [30] and Girardin et al. [31] and individually germinated on PDA. Once the single ascospore cultures had produced sufficient mycelium they were screened for the presence of AthCV-by RT-PCR using virus specific primers as described by Ejmal et al. [28]. To test for AthCV1 in sclerotia produced by $A$. niger, the sclerotia were isolated from cultures on PDA plates incubated at $37^{\circ} \mathrm{C}$ for 2 weeks in the dark, according to the method of Utkhede and Rahe [32], with minor modifications as follows: Sclerotia were picked from the agar plates with forceps and placed in a $100 \mathrm{~mL}$ beaker containing $75 \mathrm{~mL}$ sterile water, filtered through three layers of cheesecloth, washed with sterile water and surface sterilized with $0.25 \%$ sodium hypochlorite for $2 \mathrm{~min}$. The sclerotia were then immediately passed through 3 layers cheesecloth and washed again with $500 \mathrm{~mL}$ sterile water. One hundred sclerotia were individually inoculated to PDA plates and incubated at $37^{\circ} \mathrm{C}$ for 2 weeks in the dark before the resultant mycelium was screened for AthCV1 infection using one-step RT-PCR as described by Ejmal et al. [28].

\subsection{The Effects of AthCV1 on Gene Expression}

Both AthCV1-infected and uninfected cultures of A. thermomutatus, A. fumigatus, A. niger and A. nidulans were grown on sterile cellophane film overlaid on PDA media. The cultures were incubated at $37^{\circ} \mathrm{C}$ for 5 days in the dark, as described by Zhang et al. [33], to provide growth conditions similar to those used for growth and sporulation experiments. To minimize the effects of variability between cultures, three replicates for each treatment were pooled before total RNA was extracted. Thirty milligrams of mycelium from each of three plates was harvested and combined in a 2-mL Eppendorf tube and total RNA extracted using a Spectrum Plant Total RNA Kit (Sigma-Aldrich, St. Louis, MO, USA), as described by the manufacturer. A 0.1 volume of $3 \mathrm{M}$ sodium acetate, $\mathrm{pH} 5.2$ and two volumes of $100 \%$ ethanol were added to each extract to precipitate the RNA, which was sent on ice to Macrogen Inc. (Soeul, Korea), for RNA sequencing. An Agilent Technologies 2100 Bioanalyzer 2100 Bioanalyzer (Agilent Technologies, Santa Clara, CA, USA) was used to measure RNA quality and quantity of the original samples and confirm an RNA integrity number (RIN) of 8 or greater. Fragmentation was performed on RNA samples before cDNA synthesis and the cleaved RNA fragments primed with random hexamers. First strand cDNA was transcribed using reverse transcriptase according to the Truseq RNA sample preparation V2 guide (Illumina, San Diego, CA, USA). The second cDNA strand synthesis was performed using DNA polymerase I in the presence of RNase H. Adapters were ligated to the DNA and PCR amplification performed to selectively enrich DNA fragments with adapter molecules on both ends and to amplify the amount of DNA in the library. PCR amplification was conducted using a PCR Primer Cocktail which anneals to the ends of the adapters. An Agilent Technologies 2100 Bioanalyzer (Agilent Technologies, Santa Clara, CA, USA) with a DNA 1000 chip was used to verify the size of PCR-enriched fragments and for library quantification qPCR was used, according to the Illumina qPCR Quantification Protocol Guide (\# 11322363) (Illumina, San Diego, CA, USA). Indexed DNA libraries were normalized to $10 \mathrm{nM}$ in the Diluted Cluster Template (DCT) plate and then pooled in equal volumes in the Pooled DCT plate. Sequencing was conducted using the Hiseq2000 platform (Illumina, San Diego, CA, USA) which generated reads of $100 \mathrm{bp} \times 2$ (paired-end) with a total run output of 35-40 Gb. The FastQC quality control tool [34] was used to provide quality control checks on each sequence data file. 
For A. fumigatus, A. niger and A. nidulans, where a reference genome was available (fungi.ensembl. org/index.html), the Tuxedo protocol [35] was used. The 100-bp paired-end output reads data files for each treatment (5 GB each) were uploaded individually to the Galaxy-qld platform (galaxy-qld. genome.edu.au) and Tophat2, version 0.6 [36] used to align the sequences (both forward and reverse reads). Each BAM file, containing accepted hits produced by Tophat2, was then assembled using Cufflinks software version 0.0.7 [37]. Cuffmerge software version 0.0.6 [37] was then used to merge all the assembled transcripts together in one output GTF file and Cuffdiff software version 0.0.7 [37] used to identify possible significant changes in transcript expression between AthCV1-negative and positive lines. Following that, identifiers of the differentially expressed genes were used to search for their gene ontology annotations in Aspergillus genome databases (www.aspergillusgenome.org), Ensemble Fungi database (fungi.ensembl.org/index.html) and the UniProt Knowledgebase (www.uniprot.org).

For A. thermomutatus, where no reference genome was available, the Trinity de novo transcriptome assembly software (version 0.0.2) [38,39] was used to create a full-length transcriptome which can be processed by Tophat and cufflinks. The Trinity read normalization tool was used to reduce coverage of highly covered areas and then the Galaxy "concatenate datasets" tool (version 1.0.0) used to combine all normalized forward and reverse reads, for each treatment. The combined reads were then used to produce a fasta file that contained all possible assembled transcripts from both AthCV1-positive and AthCV1-negative samples. The resultant transcriptome was used for the Tuxedo protocol, as described above. From the Cuffdiff output, gene loci identifiers (e.g., comp0_c0_seq1) were used to retrieve their relevant transcripts and the DNA sequences used as queries for nucleotide BLASTn searches in GenBank, to find the closest available gene sequences, which were used to search for gene ontology annotations.

\section{Results}

\subsection{Transfection of Aspergillus Species}

AthCV1-specific RT-PCR, conducted on the third serial subcultures of A. fumigatus (Afu-13), A. niger (Ang-9) and A. nidulans (And-1), confirmed that all three species were successfully transfected with AthCV1 purified particles (Figure 1A).

\subsection{Impact of AthCV1 on Sporulation of Aspergillus Spp.}

The results for the effects of AthCV1 on sporulation of A. fumigatus (Afu-13), A. niger (Ang-9) and $A$. nidulans (And-1) at $37^{\circ} \mathrm{C}$ and $20^{\circ} \mathrm{C}$, together with the results for $A$. thermomutatus previously published [28] are presented in Table 1. In A. fumigatus, AthCV1 infection significantly reduced $(p \leq 0.05)$ asexual sporulation at both temperatures, with the effects being more extreme at $37^{\circ} \mathrm{C}$ than at $20^{\circ} \mathrm{C}$. As would be expected there was no sexual reproduction observed in either the AthCV1-free or AthCV1-infected treatments at either temperature as A. fumigatus is a heterothallic species. In the homothallic species $A$. nidulans conidial production was significantly reduced $(p \leq 0.05)$ in the AthCV1-infected line at $37^{\circ} \mathrm{C}$ but not at $20^{\circ} \mathrm{C}$, while there was a significant increase $(p \leq 0.05)$ in the number of ascospores produced by the AthCV1-infected line at both $37^{\circ} \mathrm{C}$ and $20^{\circ} \mathrm{C}$. In A. niger asexual sporulation was significantly decreased $(p \leq 0.05)$ in the AthCV1-infected line at $37^{\circ} \mathrm{C}$ while there was no significant difference between AthCV1-free and infected lines at $20^{\circ} \mathrm{C}$. A. niger also formed sclerotia in the AthCV1-Infected line at $37^{\circ} \mathrm{C}$ but not at $20^{\circ} \mathrm{C}$. There was no sexual reproduction in A. niger cultures at either temperature. 

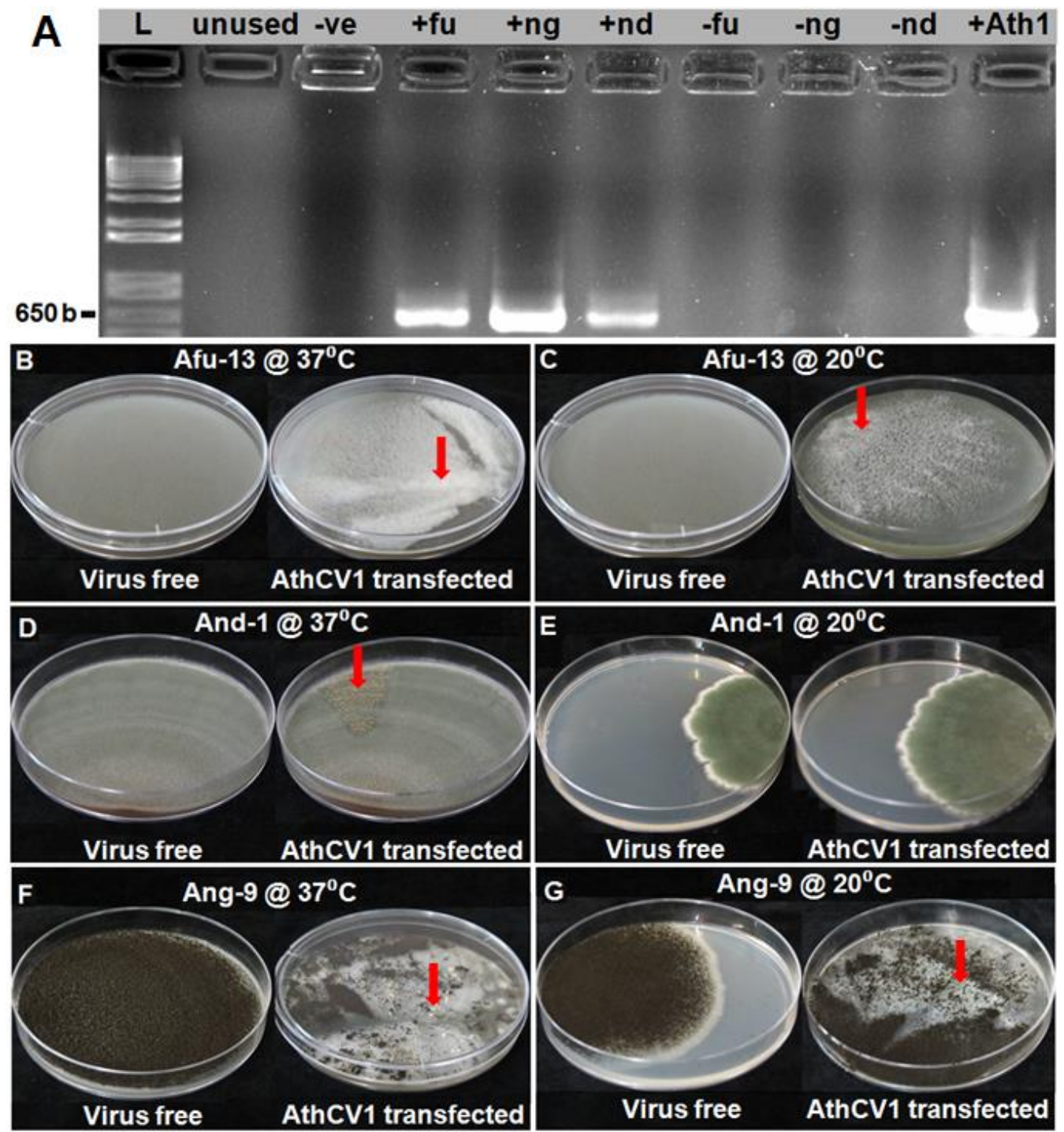

Figure 1. Effects of AthCV1 infection on the colony morphology of Aspergillus species. (A) polymerase chain reaction (PCR) assay showing successful AthCV1 transfection to different virus-free Aspergillus species; reverse transcription $\mathrm{PCR}$, lane $\mathrm{L}=1 \mathrm{~kb}$ plus DNA ladder; $-\mathrm{Ve}=\mathrm{PCR}$ negative control (RNA sample was replaced with ultrapure water) + Ath1 $=$ AthCV1 +ve control; +fu = AthCV1 transfected A. fumigatus (Afu-13); +ng = AthCV1 transfected A. niger (Ang-9); +nd = AthCV1 transfected A. nidulans (And-1); -fu, -ng and -nd = original virus-free isolates of A. fumigatus (Afu-13), A. niger (Ang-9) and $A$. nidulans (And-1), respectively. (B) Afu- 13 grown at $37^{\circ} \mathrm{C}$; normal growth in the virus-free isolate, sectors formed in isogenic AthCV1-transfected line (arrow). (C) Afu-13 grown at $20{ }^{\circ} \mathrm{C}$; normal growth in the virus-free isolate, sectors formed in isogenic AthCV1-transfected line (arrow). (D) And-1 grown at $37^{\circ} \mathrm{C}$; normal growth in the virus-free isolate, ascospore-rich sectors formed in isogenic AthCV1-transfected line (arrow). (E) And-1 grown at $37^{\circ} \mathrm{C}$; normal growth in both virus-free and AthCV1-transfected lines. (F) Ang-9 grown at $37^{\circ} \mathrm{C}$; normal growth in the virus-free isolate, conidial-free sectors with sclerotia formed (arrow) in AthCV1-transfected line. (G) Ang-9 grown at $20^{\circ} \mathrm{C}$; normal growth in the virus-free isolate, conidial- and sclerotia-free sectors in AthCV1-transfected line (arrow). 
Table 1. Summary of the effects of AthCV1 on four Aspergillus species.

\begin{tabular}{|c|c|c|c|c|c|c|c|c|c|}
\hline \multirow[b]{2}{*}{ Property } & \multirow[b]{2}{*}{ Growth Temp } & \multicolumn{2}{|c|}{ A. thermomutatus } & \multicolumn{2}{|c|}{ A. fumigatus } & \multicolumn{2}{|c|}{ A. niger } & \multicolumn{2}{|c|}{ A. nidulans } \\
\hline & & Virus-Free & AthCV1 Infected & Virus-Free & AthCV1 Infected & Virus-Free & AthCV1 Infected & Virus-Free & AthCV1 Infected \\
\hline \multirow{2}{*}{$\begin{array}{l}\text { Conidia production } \\
\text { (per plate) }\end{array}$} & $37^{\circ} \mathrm{C}$ & $2.1( \pm 0.36) \times 10^{5}$ & $2.0( \pm 0.10) \times 10^{6} *$ & $3.8( \pm 0.42) \times 10^{8}$ & $1.6( \pm 0.12) \times 10^{7 *}$ & $1.8( \pm 0.12) \times 10^{8}$ & $2.0( \pm 0.14) \times 10^{7 *}$ & $2.2( \pm 0.62) \times 10^{8}$ & $9.5( \pm 0.79) \times 10^{7 *}$ \\
\hline & $20^{\circ} \mathrm{C}$ & $2.4( \pm 0.36) \times 10^{6}$ & $2.1( \pm 0.24) \times 10^{5 *}$ & $1.5( \pm 0.21) \times 10^{8}$ & $3.6( \pm 0.31) \times 10^{7 *}$ & $2.2( \pm 0.26) \times 10^{8}$ & $1.9( \pm 0.24) \times 10^{8}$ & $1.4( \pm 0.16) \times 10^{8}$ & $1.4( \pm 0.12) \times 10^{8}$ \\
\hline \multirow{2}{*}{$\begin{array}{l}\text { Ascospore production } \\
\text { (per plate) }\end{array}$} & $37^{\circ} \mathrm{C}$ & 0 & $7.2( \pm 0.73) \times 10^{5 *}$ & 0 & 0 & 0 & 0 & $1.1( \pm 0.10) \times 10^{6}$ & $2.1( \pm 0.42) \times 10^{6 *}$ \\
\hline & $20^{\circ} \mathrm{C}$ & 0 & $3.6( \pm 0.37) \times 10^{5 *}$ & 0 & 0 & 0 & 0 & $2.9( \pm 0.22) \times 10^{5}$ & $8.0( \pm 0.55) \times 10^{5 *}$ \\
\hline \multirow{2}{*}{$\begin{array}{l}\text { Sclerotia production } \\
\text { (per plate) }\end{array}$} & $37^{\circ} \mathrm{C}$ & 0 & 0 & 0 & 0 & 0 & $54( \pm 4.2) *$ & 0 & 0 \\
\hline & $20^{\circ} \mathrm{C}$ & 0 & 0 & 0 & 0 & 0 & 0 & 0 & 0 \\
\hline \multirow{2}{*}{ Growth $(\mathrm{mm})^{1}$} & $37^{\circ} \mathrm{C}$ & $74( \pm 0.32)$ & $75( \pm 1.00)$ & $72( \pm 0.37)$ & $73( \pm 1.00)$ & $77( \pm 0.20)$ & $67( \pm 0.68)^{*}$ & $76( \pm 0.49)$ & $75( \pm 0.71)$ \\
\hline & $20^{\circ} \mathrm{C}$ & $76( \pm 0.32)$ & $75( \pm 0.32)$ & $67( \pm 0.32)$ & $72( \pm 0.20) *$ & $77( \pm 0.60)$ & $67( \pm 0.74)$ & $33( \pm 0.45)$ & $30( \pm 0.66)^{*}$ \\
\hline \multirow{2}{*}{$\begin{array}{l}\text { Fungal Biomass }{ }^{2} \\
\text { (g dry wt) }\end{array}$} & $37^{\circ} \mathrm{C}$ & $1.25( \pm 0.012)$ & $1.28( \pm 0.009)$ & $1.30( \pm 0.008)$ & $1.23( \pm 0.008)^{*}$ & $1.25( \pm 0.023)$ & $1.30( \pm 0.007)$ & $1.36( \pm 0.021)$ & $1.12( \pm 0.005)^{*}$ \\
\hline & $20^{\circ} \mathrm{C}$ & $1.13( \pm 0.011)$ & $1.13( \pm 0.009)$ & $1.15( \pm 0.011)$ & $1.13( \pm 0.007)$ & $1.09( \pm 0.004)$ & $1.12( \pm 0.003)^{*}$ & $1.12( \pm 0.016)$ & $1.12( \pm 0.010)$ \\
\hline \multirow{2}{*}{ Sector formation } & $37^{\circ} \mathrm{C}$ & & $\begin{array}{l}\text { Creamy, rough } \\
\text { ascospore-rich } \\
\text { sectors }\end{array}$ & & $\begin{array}{l}\text { Clear, elongated } \\
\text { sectors in the grey } \\
\text { mycelium }\end{array}$ & & $\begin{array}{c}\text { Conidia-free sectors } \\
\text { with no } \\
\text { pigmentation }\end{array}$ & & $\begin{array}{l}\text { Ascospore-rich } \\
\text { sectors in the green } \\
\text { mycelium }\end{array}$ \\
\hline & $20^{\circ} \mathrm{C}$ & & $\begin{array}{l}\text { Creamy, rough } \\
\text { ascospore-rich } \\
\text { sectors }\end{array}$ & & $\begin{array}{l}\text { Clear, elongated } \\
\text { sectors in the grey } \\
\text { mycelium }\end{array}$ & & $\begin{array}{c}\text { Conidia-free sectors } \\
\text { with no } \\
\text { pigmentation } \\
\end{array}$ & & No sector formation \\
\hline \multirow{2}{*}{ Pigment change } & $37^{\circ} \mathrm{C}$ & & Creamy sectors & & $\begin{array}{c}\text { Sectors lack } \\
\text { pigmentation }\end{array}$ & & $\begin{array}{c}\text { Sectors lack } \\
\text { pigmentation }\end{array}$ & & No change \\
\hline & $20^{\circ} \mathrm{C}$ & & Creamy sectors & & $\begin{array}{c}\text { Sectors lack } \\
\text { pigmentation }\end{array}$ & & $\begin{array}{c}\text { Sectors lack } \\
\text { pigmentation }\end{array}$ & & No change \\
\hline
\end{tabular}

Data analyzed by independent samples $t$-test using SPSS version 21 , SEs in brackets. ${ }^{*}=$ significant difference $(p<0.05)$ between virus-free and virus infected treatments. ${ }^{1}$ Since growth was measured to the edge of the petri dish the growth period differed for the different species: at $37^{\circ} \mathrm{C}$ A. thermomutatus $=6$ days, A. fumigatus $=6$ days, $A$. niger $=13$ days, $A$. nidulans $=13$ days; at $20^{\circ} \mathrm{C}$ A. thermomutatus $=15$ days, A. fumigatus $=24$ days, A. niger $=29$ days, $A$. nidulans $=24$ days. ${ }^{2}$ Growth in liquid culture was measured after 4 days at $37{ }^{\circ} \mathrm{C}$ and 15 days at $20{ }^{\circ} \mathrm{C}$. 


\subsection{Effects of AthCV1 on Aspergillus Growth and Morphology}

A summary of the effects of AthCV1 on the growth and the cultural characteristics of the Aspergillus species at $37{ }^{\circ} \mathrm{C}$ and $20^{\circ} \mathrm{C}$, together with the results for A. thermomutatus previously published [28], are presented in Table 1. The radial growth of A. fumigatus on PDA plates was significantly greater $(p \leq 0.05)$ in AthCV1-infected cultures at $20^{\circ} \mathrm{C}$ but not at $37^{\circ} \mathrm{C}$. In contrast, there was a significant decrease in mycelial dry weight associated with AthCV1 infection at $37^{\circ} \mathrm{C}$ but not at $20^{\circ} \mathrm{C}$. In addition, while the AthCV1-free culture produced a uniform grey-colored mycelium, the mycelium of the AthCV1-infected line formed small white sectors that subsequently merged together. This was more prominent at $37^{\circ} \mathrm{C}$ than at $20^{\circ} \mathrm{C}$, eventually covering most of the plate (Figure $1 \mathrm{~B}, \mathrm{C}$ ). In $A$. nidulans there was a significant decrease in radial mycelial growth of the AthCV1-infected line at $20^{\circ} \mathrm{C}$ while at $37^{\circ} \mathrm{C}$ there was no difference in growth between AthCV1-free and AthCV1-infected lines. Mycelial dry weight was lower in AthCV1-infected cultures at $37^{\circ} \mathrm{C}$ but there was no change in mycelial dry weight at $20^{\circ} \mathrm{C}$. A sectoring phenotype was observed in AthCV1-infected cultures grown at $37^{\circ} \mathrm{C}$ which were very rich in sexual fruiting bodies (Figure 1D) but not in those grown at $20{ }^{\circ} \mathrm{C}$ (Figure 1E). In A. niger there was a significant reduction of radial mycelial growth on PDA plates in infected cultures at $37^{\circ} \mathrm{C}$ but no difference in mycelial growth at $20^{\circ} \mathrm{C}$. There was a significant increase in mycelial dry weight in the AthCV1-infected line grown at $20{ }^{\circ} \mathrm{C}$ but no difference between virus-infected and virus-free at $37^{\circ} \mathrm{C}$. Sectors with a conidia-free phenotype occurred in the AthCV1-positive culture at both $37^{\circ} \mathrm{C}$ and $20^{\circ} \mathrm{C}$ (Figure $1 \mathrm{~F}, \mathrm{G}$ ). At $37^{\circ} \mathrm{C}$ sclerotia were formed in these conidia-free sectors (Figure $1 \mathrm{~F}$ ) but no sclerotia were formed in cultures grown at $20{ }^{\circ} \mathrm{C}$ (Figure $1 \mathrm{G}$ ).

\subsection{Transmission of AthCV1 Through Ascospores and Sclerotia}

In AthCV1 infected cultures, ascospores were produced by A. nidulans but not in A. fumigatus or A. niger. Of the single ascospore cultures grown at $37^{\circ} \mathrm{C}, 31$ of 100 were AthCV1-infected, while from the culture grown at $20^{\circ} \mathrm{C}, 34$ of 100 ascospores were infected. Sclerotia were produced in AthCV1 infected cultures of $A$. niger but not $A$. nidulans or A. fumigatus. AthCV1 was detected in 18 of 100 sclerotia produced by $A$. niger grown at $37^{\circ} \mathrm{C}$.

\subsection{Changes in Gene Expression Associated with AthCV1 Infection}

The quality and quantity check performed on the original total RNA samples indicated that all of the samples were of acceptable quality ( $\mathrm{RIN}=6.5-7.6$ ). The average RNA size was $c$. $260-280 \mathrm{bp}$, of which $126 \mathrm{bp}$ represented the Illumina sequencing adapters, yielding a gene sequence fragment of c. $140-160 \mathrm{bp}$. FastQC indicated an acceptable Phred quality score of $\geq 20$ over all samples. FastQC also confirmed that the encoding format of the data in the RNA-seq files was in "Sanger/Illumina 1.9" format as required for the Galaxy platform. De novo transcriptome assembly for A. thermomutatus, for which no genome was available by the time of the study, produced a fasta file containing 44430 sequences. FPKM (Fragments Per Kilobase of transcript, per Million mapped reads) results indicated that for AthCV1-infected cultures some genes were highly upregulated while others showed downregulation or were undetectable (i.e., showed a zero FPKM value), compared with the isogenic virus-free line. These included genes related to fungal sporulation (Table 2). The number of differentially expressed genes ( $\geq 5$-fold change or undetectable in one treatment) were 62 each in A. thermomutatus and in A. fumigatus, 65 in A. niger and 34 in A. nidulans. The functional analysis of these genes is shown in Figure 2. 
Table 2. Regulation of sporulation-related genes in AthCV1-infected Aspergillus species compared with their isogenic AthCV1-free line. Genes showing a five-fold or greater difference in expression between infected and non-infected lines are presented in the table.

\begin{tabular}{|c|c|c|}
\hline Gene ID & Verified and Predicted Gene and Function $\diamond$ retrieved from www.aspergillusgenome.org, www.uniprot.org and fungi.ensembl.org/index.html & Fold Change \\
\hline \multicolumn{3}{|c|}{ A. thermomutatus ${ }^{\Delta}$} \\
\hline NFIA_070550 & $\operatorname{csn} B$; orthologue(s) subunit2 of the COP9 signalosome; required for formation of cleistothecia & $7 \uparrow$ \\
\hline NFIA_010750 & $\begin{array}{l}\text { laeA; orthologue (laeA/AN0807, A. nidulans) coordinates asexual development in response to light, involved in the regulation of secondary } \\
\text { metabolism and required for the formation Hulle cells. }\end{array}$ & $1913 \downarrow$ \\
\hline NFIA_030070 & fhbA; flavohemoprotein, regulates sexual sporulation and sterigmatocystin production & $100 \downarrow$ \\
\hline NFIA_071100 & MAT1; positive regulation of mating type specific transcription, DNA-templated & $35 \downarrow$ \\
\hline \multicolumn{3}{|c|}{ A. fumigatus } \\
\hline Afu1g14520 & Pyridine nucleotide-disulphide oxidoreductase; NADPH dehydrogenase activity, spore germination & $25 \uparrow$ \\
\hline Afu2g17560 & Hydroxynaphthalene reductase arp2; involved in conidial pigment biosynthesis; conidia-enriched protein & $16 \uparrow$ \\
\hline Afu2g17600 & Conidial pigment polyketide synthase PksP/Alb1; conidial pigment biosynthesis; conidia wall assembly & $13 \uparrow$ \\
\hline Afu2g17550 & Heptaketide hydrolase ayg1; conidial pigment; polyketide shortening; conidia-enriched protein & $13 \uparrow$ \\
\hline Afu2g17580 & Scytalone dehydratase arp1; conidial pigment biosynthesis; conidia formation and sporulation & $9 \uparrow$ \\
\hline Afulg09750 & Aldehyde reductase (AKR1), putative; conidia-enriched protein & $38 \downarrow$ \\
\hline Afu4g10770 & ppoA; response to oxidative stress; orthologue (AN1967/ppoA) negative regulation of sexual sporulation and positive regulation asexual sporulation. & $7 \downarrow$ \\
\hline \multicolumn{3}{|c|}{ A. niger } \\
\hline An18g06650 & Orthologue (Afu3g14540, A. fumigatus), 30-kilodalton heat shock protein; conidia-enriched protein & $157 \uparrow$ \\
\hline An01g12490 & Orthologue (Neurospora crassa) has NADPH dehydrogenase activity, role in spore germination & $18 \uparrow$ \\
\hline An14g02460 & fhbA; orthologue in A. nidulans regulation of sexual sporulation and sterigmatocystin biosynthetic process & $12 \uparrow$ \\
\hline An04g07400 & $\begin{array}{l}\text { Putative C6 zinc finger transcription factor; orthologue (AN1848/nosA, A. nidulans) positive regulation of sexual development; orthologue (adv-1) in } \\
\text { N. crassa has predicted role in conidium formation and hyphal growth. }\end{array}$ & $326 \downarrow$ \\
\hline An12g00710 & Orthologue (AN9121/esdC, A. nidulans); negative regulation of conidiation and positive regulation of sexual sporulation & $200 \downarrow$ \\
\hline An02g05420 & $f l b C$; putative $\mathrm{C} 2 \mathrm{H} 2$ transcription factor; predicted role in conidiation; expressed in germinating conidia & $31 \downarrow$ \\
\hline An04g05880 & $\begin{array}{l}\text { ppoA; response to oxidative stress; orthologue (AN1967/ppoA) negative regulation of sexual sporulation and positive regulation of asexual } \\
\text { sporulation. }\end{array}$ & $20 \downarrow$ \\
\hline An01g04830 & flbD; Myb-like DNA-binding protein; positive regulation of conidiation; expressed in germinating conidia & $12 \downarrow$ \\
\hline An17g01580 & $\begin{array}{l}\text { Orthologue (AN2290/steA, A. nidulans) has negative regulation of transcription by RNA polymerase II promoter; regulation of secondary metabolite } \\
\text { biosynthetic process; sporocarp development involved in sexual reproduction }\end{array}$ & $5 \downarrow$ \\
\hline An05g00480 & stuA; positive regulation of conidium formation and conidiophore development & $5 \downarrow$ \\
\hline
\end{tabular}


Table 2. Cont.

\begin{tabular}{|c|c|c|}
\hline Gene ID & Verified and Predicted Gene and Function ${ }^{\diamond}$ retrieved from www.aspergillusgenome.org, www.uniprot.org and fungi.ensembl.org/index.html & Fold Change \\
\hline \multicolumn{3}{|c|}{ A. nidulans } \\
\hline AN7795 & gprK; positive regulation of sexual sporulation [40] & $39 \uparrow$ \\
\hline AN3387 & grrD; Putative G-protein coupled receptor; Deletion of $g p r D$ resulted in delayed conidial germination and enhanced sexual development & $16 \uparrow$ \\
\hline AN3695 & Putative anthranilate synthase with a predicted role in aromatic amino acid biosynthesis and cleistothecium development & $13 \uparrow$ \\
\hline AN7169 & fhbA; flavohemoprotein; sterigmatocystin biosynthetic process and regulates sexual development & $12 \uparrow$ \\
\hline AN5844 & Controls conidia germination and adjusts cellular substances which protect conidia against dryness [41] & $7 \uparrow$ \\
\hline AN5046 & anisin-1; asexual sporulation, response to oxidative stress and defense response & $7 \uparrow$ \\
\hline AN5156 & pho80; overexpression decreases conidiation and increases formation of cleistothecia & $6 \uparrow$ \\
\hline AN3148 & PH domain protein; have role in ascospore wall assembly, ascospore-type prospore membrane assembly & $44 \downarrow$ \\
\hline AN0387 & cry $A$; negative regulation of cleistothecium development & $37 \downarrow$ \\
\hline AN8640 & conF; Conidiation protein Con-6, putative; contributes in conidia germination and desiccation resistance & $21 \downarrow$ \\
\hline AN1848 & nos A; Zinc(II)2Cys6 putative transcription factor involved in the regulation of sexual development & $20 \downarrow$ \\
\hline AN2755 & MAT1; regulator of sexual development; acts with Mat2 HMG domain protein & $16 \downarrow$ \\
\hline AN6046 & noxR; P67phox regulatory subunit homolog; required for normal sexual and asexual development & $13 \downarrow$ \\
\hline AN6688 & asp $B$; conidiophore development and hyphal growth & $12 \downarrow$ \\
\hline AN4163 & $c p c B$; required for sexual development; positive regulation of cleistothecium development & $11 \downarrow$ \\
\hline AN4351 & palA; pH-response regulator protein palA; orthologue in Saccharomyces cerevisiae (RIM20) role in sporulation resulting in formation of a cellular spore & $6 \downarrow$ \\
\hline AN1017 & hOGA; Putative mitogen-activated protein kinase; required for sexual development and sporulation & $6 \downarrow$ \\
\hline AN7553 & 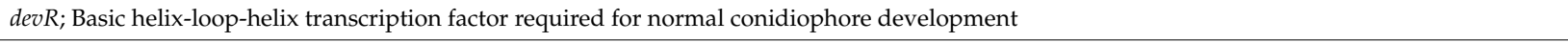 & $5 \downarrow$ \\
\hline AN10306 & candA-N; role in sexual development, secondary metabolism and light control of asexual development & $5 \downarrow$ \\
\hline AN2458 & candA-C; role in sexual development, secondary metabolism and light control of asexual development & $5 \downarrow$ \\
\hline
\end{tabular}

$\Delta=$ due to the absence of $A$. thermomutatus genome, gene orthologues of Neosartorya fischeri (closest BLAST hits) were used. $\diamond=$ function is for the gene if available or for $A$. nidulans gene orthologue. $\uparrow=$ up-regulated in the AthCV1-infected line; $\downarrow=$ down-regulated in the AthCV1-infected line. 

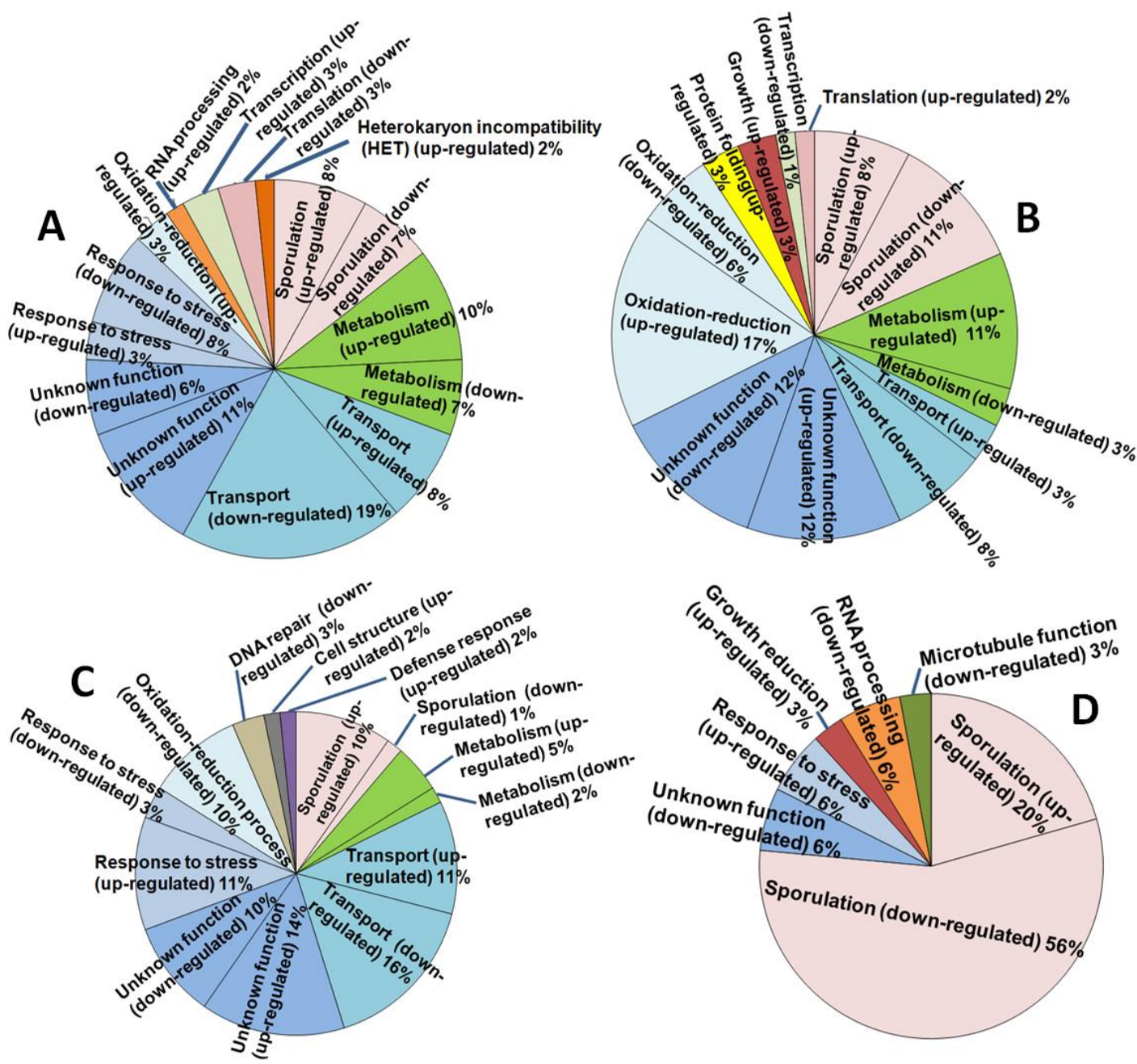

Figure 2. Differentially expressed genes in AthCV1-infected Aspergillus species and their functional analysis. (A) A. thermomutatus; (B) A. niger; (C) A. fumigatus; (D) A. nidulans.

As shown in Table 3, the effect of AthCV1 infection on gene expression varied between the different Aspergillus species. Some genes showed expression change in only one species, such as the transcription factor gene steA (AN2290), for which changes were observed only in A. niger. For other genes, the variation was just in the degree of expression, as for the orthologue of the heat shock protein gene, hsp30/hsp42 (AN5781). In other instances, the difference was in the direction of regulation, such as the internal alternative NADH dehydrogenase $n d i A$ (AN10660), which was completely repressed in A. nidulans but upregulated by 25 -fold in A. fumigatus and by 18 -fold in A. niger. The orthologue of this gene in N. crassa has an NADPH dehydrogenase activity and a role in spore germination with mitochondrial inner membrane localization (Table 2). In yeast (S. cerevisiae) overexpression of the orthologue (ndi-1) of this gene (ndiA) can result in apoptosis-like cell death, which is associated with an increase in the production of reactive oxygen species (ROS) in mitochondria [42] and the transcription factor nosA / AN1848, which in the AthCV1-infected lines was reduced 326-fold in A. niger, 20-fold in A. nidulans and 2-fold in A. fumigatus but was unchanged in A. thermomutatus. 
Table 3. Major changes in the expression of gene orthologues of AthCV1-infected Aspergillus species compared to their isogenic AthCV1-free lines.

\begin{tabular}{|c|c|c|c|c|c|}
\hline \multicolumn{5}{|c|}{ Fold Change in AthCV1-infected Samples } & \multirow{2}{*}{$\begin{array}{c}\text { Gene and Function } \\
\text { From www.uniport.org \& www.aspergillusgenome.org }\end{array}$} \\
\hline $\begin{array}{l}\text { Gene ID } \\
\text { A. nidulans }\end{array}$ & A. thermomutatus & A. fumigatus & A. nidulans & A. niger & \\
\hline AN10660 & - & 25 & - & 18 & $\begin{array}{l}\text { ndiA; Pyridine nucleotide-disulphide oxidoreductase, putative; NADPH dehydrogenase activity and spore } \\
\text { germination. }\end{array}$ \\
\hline AN2755 & -35 & - & -16 & - & MAT1: Alpha-domain mating-type protein; regulator of sexual development; acts with Mat2 HMG domain protein. \\
\hline AN1652 & - & -5 & - & - & sebA; $\mathrm{C} 2 \mathrm{H} 2$ transcription factor; required for virulence; response to oxidative stress and heat shock. \\
\hline AN5781 & - & 31 & 6 & 157 & $\begin{array}{l}\text { Heat shock protein Hsp30, transcript increase during the unfolded-protein response; palA-dependent expression } \\
\text { independent of } \mathrm{pH}\end{array}$ \\
\hline AN2458 & 3 & - & -5 & - & $\begin{array}{l}\text { canadA-C; orthologue(s) N-terminal subunit of Cand1; sexual development, secondary metabolism and light control } \\
\text { of asexual development. }\end{array}$ \\
\hline AN10306 & 5 & - & -5 & 3 & candA-N; role in sexual development and secondary metabolism. \\
\hline AN10049 & - & 9 & -4 & - & $\begin{array}{l}\text { mdpB; Probable scytalone dehydratase; involved in conidial pigment biosynthesis, conidium formation and } \\
\text { sporulation. }\end{array}$ \\
\hline AN5836 & - & - & -4 & -5 & stuA; Positive regulation of asexual sporulation and conidiophore development. \\
\hline AN1848 & - & -2 & -20 & -326 & nos $A$; Zinc(II)2Cys6 putative transcription factor; positive regulation of sexual development. \\
\hline AN5156 & -2 & - & 6 & - & Pho80-like cyclin; overexpression decreases conidiation and increases cleistothecia. \\
\hline AN7169 & -100 & 4 & 12 & 12 & $\begin{array}{l}\text { fhbA; Flavohemoglobin, negative regulation of sexual sporulation and positive regulation of sterigmatocystin } \\
\text { biosynthesis. }\end{array}$ \\
\hline AN0807 & -1913 & -2 & - & -4 & $\begin{array}{l}\text { laeA; Methyltransferase-domain protein; self-methylates; coordinates asexual development in response to light; } \\
\text { regulates secondary metabolism and is required for Hulle cell formation. }\end{array}$ \\
\hline AN0387 & - & 2 & -37 & - & cryA: Negative regulation of cleistothecium development. \\
\hline AN4783 & 7 & - & -2 & - & csnB; COP9 signalosome subunit 2 (CsnB) formation of cleistothecia. \\
\hline AN2421 & 4 & -3 & - & -31 & $f l b C$ : regulation of conidium formation and spore germination. \\
\hline AN7553 & - & -3 & -5 & - & devR; Basic helix-loop-helix transcription factor; conidiophore development. \\
\hline AN5893 & -5 & 2 & - & - & $f l b A$; Developmental regulator FlbA, conidiophore development and asexual sporulation. \\
\hline AN0082 & -6 & -2 & -2 & -2 & phnA; Phosducin, putative; regulates sporulation \\
\hline AN3387 & - & 2 & 16 & -2 & $g p r D$ : Deletion of gprD resulted in delayed conidial germination and enhanced sexual development. \\
\hline AN0279 & - & -2 & 2 & -12 & $f l b D$ : Myb-like DNA-binding protein; positive regulation of conidiation. \\
\hline AN2290 & - & - & - & -5 & $\begin{array}{l}\text { steA; Sexual development transcription factor SteA; Required for cleistothecial development and ascosporogenesis. } \\
\text { Not required for conidiation. }\end{array}$ \\
\hline AN0170 & - & - & - & -24 & $\operatorname{tr} x A_{;}$; Thioredoxin, required for conidiation; expression upregulated after exposure to farnesol. \\
\hline AN9121 & 2 & - & - & -200 & esdC; sexual development protein, involved in early sexual development and regulated by VeA and FlbA. \\
\hline AN4163 & - & 2 & -11 & - & cpcB: G-protein complex beta subunit $\mathrm{CpcB}$; positive regulation of cleistothecium development. \\
\hline AN1017 & 2 & -2 & -6 & 2 & hog $A$; Putative mitogen-activated protein kinase; required for sexual development and sporulation. \\
\hline AN7795 & - & - & 39 & - & gprK; positive regulation of sexual sporulation [40]. \\
\hline \multicolumn{2}{|c|}{ Up-regulated } & \multicolumn{2}{|c|}{ Down-regulated } & & \\
\hline Colour & $\begin{array}{c}\text { Fold change } \\
<5 \\
5 \text { to } 20 \\
21 \text { to } 100 \\
101 \text { to } 500 \\
>500\end{array}$ & Colour & $\begin{array}{c}\text { Fold change } \\
<5 \\
5 \text { to } 20 \\
21 \text { to } 100 \\
101 \text { to } 500 \\
>500\end{array}$ & & \\
\hline
\end{tabular}




\section{Discussion}

Mycoviruses have received much attention in relation to their potential as biological control agents for harmful fungi. Two necessary properties of biocontrol agents are (i) the ability to reduce the growth and virulence of the target fungus and (ii) rapid and efficient transmission of the virus from the inoculum to the target fungal population. Hyder et al. [43] found that the effects of a virus isolate on its fungal host can differ depending upon the strain of the infected fungus and that the extent of those effects can vary according to the environment and ecological conditions. Similarly, Vainio et al. [44] found that conditions (such as temperature) can alter virus impact on its fungal host. Consequently, the development of mycoviruses as effective biological control agents requires an understanding of both the viruses and their interaction with their fungal hosts and environment.

Vegetative incompatibility is a major barrier to studying the effects of viruses on a range of fungal hosts and their use in the field, as it can be a serious barrier to horizontal virus transmission between different fungal species and even different strains of the same fungal species. However, in vitro, this obstacle may be overcome by the use of protoplast fusion [45-48] or transfection of protoplasts with purified virus particles $[48,49]$. The latter technique has been successfully used for the transfection of virus-free A. fumigatus protoplasts with Aspergillus fumigatus tetramycovirus (AfuTmV-1) [50] and Aspergillus fumigatus chrysovirus (AfuCV) [24], as well as species of other fungal genera, including Botryosphaeria dothidea with Botryosphaeria dothidea chrysovirus 1 (BdCV1) [20], Rhizoctonia solani with Rhizoctonia solani partitivirus 2 [51], Cryphonectria parasitica with a reovirus from C. parasitica [52], Rosellinia necatrix with Rosellinia necatrix partitivirus (RnPV1) [53] and Rosellinia necatrix mycoreovirus 3 (RnMYRV-3) [54]. In the current study, we successfully transfected A. fumigatus, A. niger and A. nidulans with AthCV1 particles from naturally infected $A$. thermomutatus, to produce isogenic virus-free and virus-infected lines, in order to evaluate the effects of the virus on these fungal hosts.

The impact of AthCV1 infection on mycelial growth on PDA plates varied from no change at either $37^{\circ} \mathrm{C}$ or $20^{\circ} \mathrm{C}$ for $A$. thermomutatus, to significantly reduced growth for $A$. niger at $37^{\circ} \mathrm{C}$ and A. nidulans at $20^{\circ} \mathrm{C}$ and a significant increase in the growth for $A$. fumigatus at $20^{\circ} \mathrm{C}$. An increase in linear growth due to virus infection was previously reported by Nuss [55] where $C$. parasitica (strain Euro7) cultures infected with Cryphonectria hypovirus 1 (CHV-1/Euro7) showed faster growth than the isogenic virus-free isolate. However, linear growth on agar plates does not necessarily correlate with total biomass production, as seen in our experiments for A. fumigatus, A. nidulans and A. niger (Table 1), or with growth and/or pathogenicity in vivo $[56,57]$.

In the current investigation, sectoring (areas with different appearance) were observed in the virus-infected cultures of all four Aspergillus species. Sectoring has been observed in association with a range of mycoviruses including, BdCV1 [20], Helminthosporium victoriae co-infected with the totivirus, Helminthosporium victoriae virus $190 \mathrm{~S}$ (HvV190S) and the chrysovirus, Helminthosporium victoriae virus 145s (HvV145S) [56]. In a study by Bhatti et al. [24], A. fumigatus formed non-sporulating sectors when infected with A. fumigatus partitivirus 1 (AfuPV-1) or with AfuCV. However, the basis of fungal sectoring can have a number of underlying causes other than virus infection.

Although virus infection resulted in changes in sporulation and phenotype of all three species, the different Aspergillus species did not respond to AthCV1 infection in the same way. The response was often temperature dependent; $A$. fumigatus reacted consistently at both temperatures with significantly reduced conidial production (Table 1 ), whereas $A$. thermomutatus showed a significant increase in conidia at $37^{\circ} \mathrm{C}$ but produced significantly fewer conidia at $20^{\circ} \mathrm{C}$ (Table 1). In the AthCV1-infected A. nidulans (homothallic), ascospore production was significantly increased at both $37^{\circ} \mathrm{C}(90 \%)$ and $20{ }^{\circ} \mathrm{C}(170 \%)$ compared to uninfected. A. thermomutatus (also homothallic) produced ascospores only when infected with AthCV1 (Table 1), although the number produced at $20^{\circ} \mathrm{C}$ was about half that produced at $37^{\circ} \mathrm{C}$ (Table 1). Individual isolates of $A$. niger and A. fumigatus do not produce ascospores in culture as these species are not homothallic.

Since vertical transmission and dissemination of virus infection is largely dependent on spores, the rate of infection in spores is an important factor. For many fungi, virus transmission through conidia 
is often high $(<100 \%)[47,58,59]$, while transmission via ascospores is generally less efficient [60,61]. Coenen et al. [62] concluded that vertical transfer of dsRNA viruses in A. nidulans did not occur through ascospores resulting in the exclusion of viruses in the fungal population, presumably because vegetative incompatible groups formed as a result of sexual recombination in the successive generations. However, other studies have shown varying degrees of virus transmission through ascospores, including transmission of Botrytis Virus X (BVX) through ascospores in Botrytis cinerea [63], dsRNA virus particles in S. cerevisiae [64] and two different dsRNA mycoviruses in Fusarium graminearum [58]. In the current study AthCV1 was detected in $34 \%$ and $31 \%$ of ascospores at $20^{\circ} \mathrm{C}$ and $37{ }^{\circ} \mathrm{C}$, respectively.

The production of large numbers of ascospores in AthCV-1 infected A. thermomutatus, compared to no ascospores in the virus-free line and a significant increase in ascospore production in $A$. nidulans, together with the decrease in conidial production, could be the result of physiological stress due to AthCV1 infection, as stress is often a trigger for a change from asexual to sexual reproduction in fungi [65]. Therefore, AthCV1 could potentially increase sexual diversity of the fungus by stimulating ascospore production, creating the opportunity for increased gene sharing and increased sexual diversity. In addition, sclerotia, which are often produced under nutrient-depleted conditions (e.g., in old cultures) and are thought essential for sexual reproduction in Aspergillus sections Flavi [40] and Circumdati [66] and A. japonicas [67], were produced in $A$. niger at $37^{\circ} \mathrm{C}$. Frisvad et al. [66] were the first to report the production of sclerotia by $A$. niger although most of the $A$. niger strains used in their study failed to produce sclerotia despite the multiple attempts to enhance the process. It is possible that mycovirus infection affected their two strains that produced sclerotia, however the strains used in their study were screened for the presence of mycoviruses. In summary, the findings in this study indicate that AthCV1 infection enhances sexual sporulation in $A$. nidulans and $A$. thermomutatus and possibly also in $A$. niger where sclerotia were produced at $37^{\circ} \mathrm{C}$.

In the current study variability in the nature of the sectoring phenotype and differences in sporulation, mycelial growth diameter and mycelial dry weight associated with AthCV1 infection in the four different Aspergillus species demonstrate that the effect of AthCV1 is both species dependent and temperature dependent.

Given that AthCV1 has significant effects on asexual and sexual spore reproduction in some Aspergillus species, knowledge of which metabolic pathways are affected might possibly be exploited for better control of the fungus. Consequently, preliminary gene expression data, based on pooled samples of three replicate cultures for each treatment, were obtained to identify changes in the expression of known reproduction-related genes as a starting point for future, more extensive studies. In response to AthCV1 infection changes in expression were detected in a total of 223 different genes, across the four Aspergillus species examined. Genes specifically related to sporulation and/or reproduction numbered 54 , those showing greater than five-fold changes (either + or - ) are presented in Table 2.

An important family of genes for sexual reproduction in fungi are the Mating Type (MAT) genes which enable homothallic fungi to switch their mating type. In A. nidulans, Paoletti et al. [68] have shown that overexpression of MAT2 represses MAT1 expression and vice versa. The current findings reflect this with the two homothallic species $A$. thermomutatus and $A$. nidulans where MAT1/NFIA_071100 and MAT1/AN2755 were downregulated in the AthCV1-infected treatment by 8 -fold and 16-fold respectively whereas, MAT2 was upregulated by 4-fold in the AthCV1-infected A. nidulans and expressed in the AthCV1-infected $A$. thermomutatus but not in the virus-free line.

In AthCV1-infected $A$. nidulans, other highly upregulated genes that contribute to the increase in sexual sporulation include: gprk/AN7795 [40] (39-fold increase) and AN3695 (www.aspergillusgenome. org) (13-fold), fhbA/AN7169 [69] (12-fold). Genes that were undetected and whose repression might have contributed to the high reduction in conidiation include mst1/AN5674 (positive regulation of asexual development and negative regulation of sexual development) [70] and nudF/AN6197 (positive regulation of conidiation and ascospore production) [71]. In addition, genes that might have a negative impact on sexual reproduction if overexpressed and were somewhat downregulated included 
cryA/AN0387 (37-fold decrease) that codes for a blue light- and UVA-sensing cryptochrome that represses sexual development by regulating other regulators such as VeA, NsdD and RosA [72] and hogA/AN1017 (6-fold decrease) which is a putative mitogen-activated protein kinase (MAPK), is highly up-regulated under osmotic stress conditions required for sexual development and sporulation [73]. In AthCV1-infected A. nidulans conidiation was hugely reduced and this seems consistent with the increased number of ascospores, as it is known that ascospore production can inhibit conidiation and vice versa [40]. Changes in expression of genes known to be involved in the reduction of conidiation included the downregulation of conF/AN8640 (21-fold reduction) which contributes in conidia germination and in the protection of conidia against desiccation [41], noxR/AN6046 (13-fold reduction) which is important for conidiophore development and conidia production [74] and the putative septin B, aspB / AN6688 (12-fold reduction), which plays a role in growth emergence and conidiation $[75,76]$.

In AthCV1-infected A. thermomutatus there was a 7-fold increase in expression of $\operatorname{csn} B$ /NFIA_070550, which is essential for cleistothecia and ascospore formation $[77,78]$. The expression of laeA/NFIA_010750, an orthologue of the global regulator of secondary metabolism (laeA/AN0807), was downregulated by 1913-fold. This gene coordinates asexual development in response to light, is involved in the regulation of secondary metabolism and is required for the formation of Hulle cells [79-83]. The NirA-dependent flavohemoprotein gene (fhbA/NFIA_030070), which is involved in the positive regulation of sterigmatocystin production and in the negative regulation of sexual sporulation [69], was downregulated by 100-fold.

Genes of $A$. niger that were affected and possibly contributed to the huge decrease of conidiation in the AthCV1-infected treatment at $37{ }^{\circ} \mathrm{C}$ included: the putative $\mathrm{C} 2 \mathrm{H} 2$ transcription factor (flbC/An02g05420) which showed a 31-fold downregulation and has a predicted role in conidiation and is expressed in germinating conidia [84-86]; An04g07400 (326-fold reduction) an orthologue of $a d v-1$ in N. crassa which is required for normal sexual and asexual development [87]; ppoA/An04g05880 (20-fold decrease in expression), the miss expression of the A. nidulans orthologue ppoA/AN1967 leads to a decreased level of conidiation (http:/ / www.aspergillusgenome.org); and An05g00480 (5-fold reduction) which is expressed in germinating conidia and has a predicted role in positive regulation of conidiophore development and conidium formation (www.aspergillusgenome.org). In addition, An14g02540, the orthologue of the sclerotium regulator in A. oryzae (sclR/AO090011000215), that encodes a transcription factor with a role in hyphal morphology and the promotion of sclerotial production [88], was upregulated by 11-fold in the AthCV1-infected treatment. This is possibly an indication that the production of sclerotia was also related to stress, as they are survival structures typically produced in response to environmental stress [89]. Also, An18g06650, which has a strong similarity to $A$. nidulans heat shock protein 30 (hsp30/AN2530) [86], showed a 157-fold increase in expression. An orthologue of this gene in A. fumigatus, Afu3g14540 (hsp30), has been found to be expressed in a high abundance in conidia and is known to increase in response to the antifungal amphotericin B and to hydrogen peroxide [90,91].

Transcriptome analysis of the heterothallic A. fumigatus revealed the greatest upregulation (6427-fold increase) for Afu1g04410, which has no known function and the greatest downregulation (18094-fold reduction) for the DNA N-glycosylase, putative (Afu7g05320), the orthologue of which in S. cerevisiae has a predicted role in oxidized purine nucleobase lesion DNA N-glycosylase activity and molecular function in DNA damage repair (www.uniprot.org). Other A. fumigatus genes that showed altered transcription levels due to AthCV1 infection were: ppoA/Afu4g10770 (7-fold reduction), an orthologue of $A$. nidulans ppoA/AN1967, which is involved in the response to oxidative stress, negative regulation of sexual sporulation and positive regulation asexual sporulation [92] and Afu1g09750 (38-fold reduction) which is reported to be enriched in conidia compared to mycelium of A. fumigatus [90]; and Afu1g14520 (25-fold increase) which is orthologous to N. crassa (ndi-1) and has a predicted role in oxidation-reduction process and spore germination [93]. In addition, conidial pigmentation biosynthesis genes that were highly expressed in AthCV1-infected A. fumigatus 
included: Scytalone dehydratase arp1/Afu2g17580 (9-fold increase), which is involved in conidial pigment biosynthesis and for which mutants display increased C3 complement binding [94,95]; Afu2g17550/ayg1 which is involved in conidial pigment biosynthesis with a role in polyketide shortening and melanin biosynthesis in Aspergillus fumigatus [94,96]; pksP/Afu2g17600 (12-fold increase) which is involved in biosynthesis of the conidial pigment and asexual spore wall assembly [97]; arp2 / Afu2g17560 (16-fold increase) which is involved in conidial pigment biosynthesis and expression of conidia-enriched protein $[90,94]$. The latter three genes may be important virulence factors in the establishment of infection as mutations in these genes showed increased virulence and failed to inhibit phagolysosome acidification in their insect host Galleria mellonella [98].

In response to AthCV1 infection all four of the Aspergillus species included in this study exhibited changes in phenotype (Table 1) and gene expression (Table 3). For some factors, similar changes were observed in two or more of the Aspergillus species while for others the different species varied in their response. This is similar to the findings of Hyder et al. [43] who studied two viruses of the wood decay fungus Heterobasidion and reported that (i) a specific virus strain can cause different effects on different Heterobasidion strains and (ii) the impact of a single virus strain on a certain Heterobasidion isolate can differ according to the changes in environmental conditions. The diversity in response of the four Aspergillus species to AthCV1 supports the proposition that even if a particular mycovirus is found to have a hypovirulent effect on a certain fungal isolate, it does not necessarily follow that it will have the same effect on other isolates of the same or closely related species. Consequently, any evaluation of the potential of mycoviruses as biological control agents should be conducted on a range of fungal isolates in a range of environmental conditions. In the current study, differences in the expression of the internal alternative NADH dehydrogenase NdiA (AN10660) in different Aspergillus species is probably a good example of this phenomenon as it was upregulated by 25 -fold in $A$. fumigatus and by 18 -fold in A. niger but entirely repressed in A. nidulans.

In-vitro transfection can be used to experimentally extend the host range of a mycovirus in order to investigate the potential effects on new fungal hosts. This ability to overcome the barriers caused by hyphal incompatibility and genetic diversity may, if it results in stable transfected lines, extend the application of mycoviruses, such as AthCV1, for fungal disease control. However, it is important to understand the wider implications of specific phenotypic changes (e.g., spore production), observed under controlled experimental conditions, to the epidemiology of the fungus in the environment. For example, while the low conidiation rate of AthCV1-infected A. fumigatus and A. niger may reduce the ability of the fungus to spread and compete with uninfected fungal isolates in the field and thereby limit the impact of AthCV1 on Aspergillus, the high number of ascospores produced by the AthCV1-positive $A$. nidulans and $A$. thermomutatus and the enhancement of sclerotia production in $A$. niger may improve the survival of these fungi, as these structures typically resist adverse environmental changes better than conidiospores. Moreover, the presence of virus could directly or indirectly, increase diversity of Aspergillus by stimulating sexual reproduction and possibly increase the percentage of vegetatively compatible fungal strains allowing virus spread between them.

The use of mycoviruses as effective biological control agents requires consideration of multiple factors (host, virus and environment). The first objective is to find a virus that is capable of inducing serious impact on its fungal host. Once such a virus is identified, intensive research on how and when to use the virus is required, for example, direct application to the site of infection in the case of chestnut blight control [99]. A major constraint on the use of mycoviruses is that natural horizontal virus spread typically requires hyphal anastomosis, which is limited by genetically controlled hyphal incompatibility. Consequently, the direct use of mycoviruses as biological control agents, especially in a clinical context, is very challenging. However, an understanding of the molecular nature of the hypovirulence caused by a particular mycovirus may enable the development of a more direct approach such as targeting the expression of certain genes by pharmaceuticals that mimic the mechanism of hypovirulence. 
Author Contributions: Conceptualization, D.J.H. and M.N.P.; Data curation, M.A.E.; Formal analysis, M.A.E., R.M.M. and M.N.P.; Investigation, M.A.E.; Methodology, M.A.E.; Supervision, D.J.H. and M.N.P.; Writingoriginal draft, M.A.E.; Writing-review \& editing, D.J.H., R.M.M. and M.N.P.

Acknowledgments: We thank the School of Biological Sciences at the University of Auckland for funding this study. We also would like to thank Wendy McKinney from LabPlus, Auckland for providing us with the A. nidulans And-1 isolate. We appreciate the assistance of Damien Fleetwood and Mostafa Rahnama from the School of Biological Sciences, The University of Auckland, in the initial analysis of the gene expression data.

Conflicts of Interest: The authors declare no conflict of interest.

\section{References}

1. Son, M.; Yu, J.; Kim, K.H. Five Questions about Mycoviruses. PLoS Pathog. 2015, 11, e1005172. [CrossRef] [PubMed]

2. Pearson, M.N.; Beever, R.E.; Boine, B.; Arthur, K. Mycoviruses of filamentous fungi and their relevance to plant pathology. Mol. Plant. Pathol. 2009, 10, 115-128. [CrossRef] [PubMed]

3. Boddy, L. Interactions between fungi and other microbes. In The Fungi; Watkinson, S.C., Money, N., Boddy, L., Eds.; Academic Press: Cambridge, MA, USA, 2016; pp. 337-360.

4. Yu, X.; Li, B.; Fu, Y.; Xie, J.; Cheng, J.; Ghabrial, S.A.; Li, G.; Yi, X.; Jiang, D. Extracellular transmission of a DNA mycovirus and its use as a natural fungicide. Proc. Natl. Acad. Sci. USA 2013, 110, 1452-1457. [CrossRef] [PubMed]

5. Marzano, S.L.; Nelson, B.D.; Ajayi-Oyetunde, O.; Bradley, C.A.; Hughes, T.J.; Hartman, G.L.; Eastburn, D.M.; Domier, L.L. Identification of Diverse Mycoviruses through Metatranscriptomics Characterization of the Viromes of Five Major Fungal Plant Pathogens. J. Virol. 2016, 90, 6846-6863. [CrossRef] [PubMed]

6. Liu, S.; Xie, J.; Cheng, J.; Li, B.; Chen, T.; Fu, Y.; Li, G.; Wang, M.; Jin, H.; Wan, H.; et al. Fungal DNA virus infects a mycophagous insect and utilizes it as a transmission vector. PNAS 2016, 113, 12803-12808. [CrossRef] [PubMed]

7. Boland, G.J.; Mould, M.J.R.; Robb, J. Ultrastructure of a hypovirulent isolate of Sclerotinia sclerotiorum containing double stranded RNA. Physiol. Mol. Plant. Pathol. 1993, 43, 21-32. [CrossRef]

8. Hammar, S. Association of double-stranded RNA with low virulence in an isolate of Leucostoma persoonii. Phytopathology 1989, 79, 568-572. [CrossRef]

9. Boland, G.J. Hypovirulence and double stranded RNA in Sclerotinia sclerotiorum. Can. J. Plant. Pathol. 1992, 14, 10-17. [CrossRef]

10. Bottacin, A.M.; Levesque, C.A.; Punja, Z.K. Characterization of dsRNA in Chalara elegans and effects on growth and virulence. Phytopathology 1994, 84, 303-312. [CrossRef]

11. Punja, Z.K. Influence of double-stranded RNAs on growth, sporulation, pathogenicity and survival of Chalara elegans. Can. J. Bot. 1995, 73, 1001-1009. [CrossRef]

12. Newhouse, J.R.; Hoch, H.C.; Macdonald, W.L. The ultra structure of Endothia parasitica. Comparison of a virulent with a hypovirulent isolate. Can. J. Botany. 1983, 61, 389-399. [CrossRef]

13. Chu, M.; Jean, J.; Yea, S.J.; Kim, Y.H.; Lee, Y.W.; Kim, K.H. Double-strand RNA mycoviruses from Fusarium graminearum. Appl. Environ. Microbiol. 2002, 68, 2529-2534. [CrossRef] [PubMed]

14. Rigling, D.; van Alfen, N.K. Extra and intracellular laccase activity of the Chestnut blight fungus, Cryphonectria paraesitica. Appl. Environ. Microbial. 1993, 59, 3634-3639.

15. Márquez, L.M.; Redman, R.S.; Rodriguez, R.J.; Roossinck, M.J. A Virus in a Fungus in a Plant: Three-Way Symbiosis Required for Thermal Tolerance. Science 2007, 315, 513-515. [CrossRef] [PubMed]

16. Magliani, W.; Conti, S.; Gerloni, M.; Bertolotti, D.; Polonelli, L. Yeast killer systems. Clin. Microbiol. Rev. 1997, 10, 369-400. [PubMed]

17. Park, C.M.; Banerjee, N.; Koltin, Y.; Bruenn, J.A. The Ustilago maydis virally encoded KP1 killer toxin. Mol. Microbiol. 1996, 20, 957-963. [CrossRef] [PubMed]

18. Banks, G.T.; Buck, K.W.; Chain, E.B.; Darbyshire, J.E.; Himmelweit, F.; Ratti, G.; Sharpe, T.J.; Planterose, D.N. Antiviral activity of double stranded RNA from a virus isolated from Aspergillus foetidus. Nature 1970, 227, 505-507. [CrossRef] [PubMed] 
19. Ghabrial, S.A.; Caston, J.R. Family Chrysoviridae, genus Chrysovirus. In Virus Taxonomy: Classification and Nomenclature of Viruses; Ninth Report of the International Committee on Taxonomy of Viruses; King, A.M.Q., Adams, M.J., Carstens, E.B., Lefkowitz, E.J., Eds.; Elsevier: Amsterdam, The Netherlands; Academic Press: Cambridge, MA, USA, 2012; pp. 509-513.

20. Wang, L.; Jiang, J.; Wang, Y.; Hong, N.; Zhang, F.; Xu, W.; Wang, G. Hypovirulence of the Phytopathogenic Fungus Botryosphaeria dothidea: Association with a Coinfecting Chrysovirus and a Partitivirus. J. Virol. 2014, 88, 7517-7527. [CrossRef] [PubMed]

21. Urayama, S.; Kato, S.; Suzuki, Y.; Aoki, N.; Le, M.T.; Arie, T.; Teraoka, T.; Fukuhara, T.; Moriyama, H. Mycoviruses related to chrysovirus affect vegetative growth in the rice blast fungus Magnaporthe oryzae. J. Gen. Virol. 2010, 91, 3085-3094. [CrossRef] [PubMed]

22. Urayama, S.; Sakoda, H.; Katoh, Y.; Takai, R.; Le, T.M.; Fukuhara, T.; Arie, T.; Teraoka, T.; Moriyama, H. A dsRNA mycovirus, Magnaporthe oryzae chrysovirus1-B, suppresses vegetative growth and development of the rice blast fungus. Virology 2014, 448, 265-273. [CrossRef] [PubMed]

23. Ding, Z.; Zhou, T.; Guo, L.Y. Characterization of a novel strain of Botryosphaeria dothidea chrysovirus 1 from the apple white rot pathogen Botryosphaeria dothidea. Arch. Virol. 2017, 162, 2097-2102. [CrossRef] [PubMed]

24. Bhatti, M.F.; Jamal, A.; Petrou, M.A.; Cairns, T.C.; Bignell, E.M.; Coutts, R.H.A. The effects of dsRNA mycoviruses on growth and murine virulence of Aspergillus fumigatus. Fungal Genet. Biol. 2011, 48, 1071-1075. [CrossRef] [PubMed]

25. Hammond, T.M.; Andrewski, M.D.; Roossinck, M.J.; Keller, N.P. Aspergillus mycoviruses are targets and suppressors of RNA silencing. Eukaryotic Cell 2008, 7, 350-357. [CrossRef] [PubMed]

26. Lee, K.M.; Cho, W.K.; Yu, J.; Son, M.; Choi, H.; Min, K.; Lee, Y.W.; Kim, K.H. A Comparison of Transcriptional Patterns and Mycological Phenotypes following Infection of Fusarium graminearum by Four Mycoviruses. PLoS ONE 2014, 9, e100989. [CrossRef] [PubMed]

27. Sun, L.; Nuss, D.L.; Suzuki, N. Synergism between a mycoreovirus and a hypovirus mediated by the papain-like protease p29 of the prototypic hypovirus CHV1-EP. J. Gen. Virol. 2006, 87, 3703-3714. [CrossRef] [PubMed]

28. Ejmal, M.A.; Holland, D.J.; MacDiarmid, R.M.; Pearson, M.N. A novel chrysovirus from a clinical isolate of Aspergillus thermomutatus affects sporulation. PLOS ONE. under review.

29. Aneja, K.R. Experiments in Microbiology, Plant Pathology and Biotechnology; New Age International (P) Ltd.: New Delhi, India, 2003.

30. O'Gorman, C.M.; Fuller, H.T.; Dyer, P.S. Discovery of a sexual cycle in the opportunistic fungal pathogen Aspergillus fumigatus. Nature 2009, 457, 471-474. [CrossRef] [PubMed]

31. Girardin, H.; Monod, M.; Latge, J. Molecular Characterization of the Food-Borne Fungus Neosartorya fischeri (Malloch and Cain). Appl. Environ. Microbiol. 1995, 61, 1378-1383. [PubMed]

32. Utkhede, R.S.; Rahe, J.E. Wet-sieving floatation technique for isolation of sclerotia of Sclerotium cepivorum from muck soil. Phytopathology 1979, 69, 295-297. [CrossRef]

33. Zhang, F.; Guo, Z.; Zhong, H.; Wang, S.; Yang, W.; Liu, Y.; Wang, S. RNA-Seq-based transcriptome analysis of aflatoxigenic Aspergillus flavus in response to water activity. Toxins 2014, 6, 3187-3207. [CrossRef] [PubMed]

34. Andrews, S. FastQC: A Quality Control Tool for High Throughput Sequence Data. Available online: http:/ / www.bioinformatics.babraham.ac.uk/projects / fastqc (accessed on 12 December 2016).

35. Trapnell, C.; Roberts, A.; Goff, L.; Pertea, G.; Kim, D.; Kelley, D.R.; Pimentel, H.; Salzberg, S.L.; Rinn, J.L.; Pachter, L. Differential gene and transcript expression analysis of RNA-seq experiments with TopHat and Cufflinks. Nat. Protoc. 2012, 7, 562-578. [CrossRef] [PubMed]

36. Kim, D.; Pertea, G.; Trapnell, C.; Pimentel, H.; Kelley, R.; Salzberg, S.L. TopHat2: Accurate alignment of transcriptomes in the presence of insertions, deletions and gene fusions. Genome Biol. 2013, 14, R36. [CrossRef] [PubMed]

37. Trapnell, C.; Williams, B.A.; Pertea, G.; Mortazavi, A.M.; Kwan, G.; van Baren, M.J.; Salzberg, S.L.; Wold, B.; Pachter, L. Transcript assembly and abundance estimation from RNA-Seq reveals thousands of new transcripts and switching among isoforms. Nat. Biotechnol. 2010, 28, 511-515. [CrossRef] [PubMed]

38. Grabherr, M.G.; Haas, B.J.; Yassour, M.; Levin, J.Z.; Thompson, D.A.; Amit, I.; Adiconis, X.; Fan, L.; Raychowdhury, R.; Zeng, Q.; et al. Full-length transcriptome assembly from RNA-Seq data without a reference genome. Nat. Biotechnol. 2011, 29, 644-652. [CrossRef] [PubMed] 
39. Haas, J.H.; Papanicolaou, A.; Yassour, M.; Grabherr, M.; Blood, P.D.; Bowden, J.; Couger, M.B.; Eccles, D.; Li, B.; Lieber, M.; et al. De novo transcript sequence reconstruction from RNA-seq using the Trinity platform for reference generation and analysis. Nat. Protoc. 2013, 8, 1494-1512. [CrossRef] [PubMed]

40. Dyer, P.S.; O'Gorman, C.M. Sexual development and cryptic sexuality in fungi: Insights from Aspergillus species. FEMS Microbiol. Rev. 2012, 36, 165-192. [CrossRef] [PubMed]

41. Suzuki, S.; Sarikaya Bayram, Ö.; Bayram, Ö.; Braus, G.H. ConF and conJ contribute to conidia germination and stress response in the filamentous fungus Aspergillus nidulans. Fungal Genet. Biol. 2013, 56, 42-53. [CrossRef] [PubMed]

42. Li, W.; Sun, L.; Liang, Q.; Wang, J.; Mo, W.; Zhou, B. Yeast AMID homologue Ndi1p displays respiration-restricted apoptotic activity and is involved in chronological aging. Mol. Biol. Cell 2006, 17, 1802-1811. [CrossRef] [PubMed]

43. Hyder, R.; Pennanen, T.; Hamberg, L.; Vainio, E.J.; Piri, T.; Hantula, J. Two viruses of Heterobasidion confer beneficial, cryptic or detrimental effects to their hosts in different situations. Fungal Ecology 2013, 6, 387-396. [CrossRef]

44. Vainio, E.J.; Korhonen, K.; Tuomivirta, T.T.; Hantula, J. A novel putative partitivirus of the saprotrophic fungus Heterobasidion ecrustosum infects pathogenic species of the Heterobasidion annosum complex. Fungal Biology 2010, 114, 955-965. [CrossRef] [PubMed]

45. Madhosingh, C. Production of intraspecific hybrids of Fusarium oxysporum f. sp. radicis-lycopersici and Fusarium oxysporum f. sp. lycopersici by protoplast fusions. J. Phytopathol. 1994, 142, 301-309. [CrossRef]

46. Van Diepeningen, A.D.; Debets, A.J.; Hoekstra, R.F. Intra- and interspecies virus transfer in Aspergilli via protoplast fusion. Fungal Genet. Biol. 1998, 25, 171-180. [CrossRef] [PubMed]

47. Van Diepeningen, A.D.; Varga, J.; Hoekstra, R.F.; Debets, A.J. Mycoviruses in Aspergilli. In Aspergillus in the genomics era; Samson, R., Varga, J., Eds.; Wageningen Academic Publishers: Wageningen, The Netherlands, 2008; p. 133. ISBN 978-90-8686-065-4.

48. Kanematsu, S.; Sasaki, A.; Onoue, M.; Oikawa, Y.; Ito, T. Extending the fungal host range of a partitivirus and a mycoreovirus from Rosellinia necatrix by Inoculation of protoplasts with virus particles. Phytopathology. 2010, 100, 922-930. [CrossRef] [PubMed]

49. Lee, K.M.; Yu, J.; Son, M.; Lee, Y.W.; Kim, K.H. Transmission of Fusarium boothii mycovirus via protoplast fusion causes hypovirulence in other phytopathogenic fungi. PLoS ONE 2011, 6, e21629. [CrossRef] [PubMed]

50. Kanhayuwa, L.; Kotta-Loizou, I.; Özkan, S.; Gunning, A.P.; Coutts, R.H. A novel mycovirus from Aspergillus fumigatus contains four unique dsRNAs as its genome and is infectious as dsRNA. Proc. Natl. Acad. Sci. USA 2015, 112, 9100-9105. [CrossRef] [PubMed]

51. Zheng, L.; Zhang, M.; Chen, Q.; Zhu, M.; Zhou, E. A novel mycovirus closely related to viruses in the genus Alphapartitivirus confers hypovirulence in the phytopathogenic fungus Rhizoctonia solani. Virology 2014, 456-457, 220-226. [CrossRef] [PubMed]

52. Hillman, B.I.; Supyani, S.; Kondo, H.; Suzuki, N. A Reovirus of the fungus Cryphonectria parasitica that is infectious as particles and related to the Coltivirus genus of animal pathogens. J. Virol. 2004, 78, 892-898. [CrossRef] [PubMed]

53. Sasaki, A.; Kanematsu, S.; Onoue, M.; Oyama, Y.; Yoshida, K. Infection of Rosellinia necatrix with purified viral particles of a member of Partitiviridae (RnPV1-W8). Arch Virol. 2006, 151, 697-707. [CrossRef] [PubMed]

54. Sasaki, A.; Kanematsu, S.; Onoue, M.; Oikawa, Y.; Nakamura, H.; Yoshida, K. Artificial Infection of Rosellinia necatrix with Purified Viral Particles of a Member of the Genus Mycoreovirus Reveals Its Uneven Distribution in Single Colonies. Phytopathology 2007, 97, 278-286. [CrossRef] [PubMed]

55. Nuss, D.L. Hypovirulence: Mycoviruses at the fungal-plant interface. Nat. Rev. Microbiol. 2005, 3, 632-642. [CrossRef] [PubMed]

56. Ghabrial, S.A.; Suzuki, N. Viruses of Plant Pathogenic Fungi. Annu. Rev. Phytopathol. 2009, 47, $353-384$. [CrossRef] [PubMed]

57. Romeralo, C.; Bezos, D.; Martínez-Álvarez, P.; Diez, J.J. Vertical Transmission of Fusarium circinatum Mitoviruses FcMV1 and FcMV2-2 via Microconidia. Forests 2018, 9, 356. [CrossRef]

58. Chu, Y.M.; Lim, W.S.; Yea, S.J.; Cho, J.D.; Lee, Y.W.; Kim, K.H. Complexity of dsRNA mycovirus isolated from Fusarium graminearum. Virus Genes 2004, 28, 135-143. [CrossRef] [PubMed]

59. Milgroom, M.G.; Cortesi, P. Biological control of chestnut blight with hypovirulence: A critical analysis. Annu. Rev. Phytopathol. 2004, 42, 3113-3118. [CrossRef] [PubMed] 
60. Van Diepeningen, A.D.; Debets, A.J.; Hoekstra, R.F. Heterokaryon incompatibility blocks virus transfer among natural isolates of black Aspergilli. Curr. Genet. 1997, 32, 2091-2097. [CrossRef]

61. Refos, J.M.; Vonk, A.G.; Eadie, K.; Lo-Ten-Foe, J.R.; Verbrugh, H.A.; van Diepeningen, A.D.; van de Sande, W.W. Double-Stranded RNA Mycovirus Infection of Aspergillus fumigatus is Not Dependent on the Genetic Make-Up of the Host. PLoS ONE 2013, 8, e77381. [CrossRef] [PubMed]

62. Coenen, A.; Kevei, F.; Hoekstra, R.F. Factors affecting the spread of double-stranded RNA viruses in Aspergillus nidulans. Genet. Res. 1997, 69, 1-10. [CrossRef] [PubMed]

63. Tan, C.M.C.; Pearson, M.N.; Beever, R.E.; Parkes, S.L. Why Fungi Have Sex? In 14th International Botrytis Symposium abstract book; Cape Town, South Africa, 2007; p. 26.

64. Brewer, B.J.; Fangman, W.L. Preferential inclusion of extrachromosomal genetic elements in yeast meiotic spores. Proc. Nat. Acad. Sci. USA 1980, 77, 5380-5384. [CrossRef]

65. Bell, G. The Masterpiece of Nature: The Evolution and Genetics of Sexuality; University of California Press: Berkeley, CA, USA, 1982.

66. Frisvad, J.C.; Petersen, L.M.; Lyhne, K.; Larsen, T.O. Formation of sclerotia and production of indoloterpenes by Aspergillus niger and other species in section Nigri. PLoS ONE 2014, 9, e94857. [CrossRef] [PubMed]

67. Rajendran, C.; Muthappa, B.N. Saitoa, a new genus of Plectomycetes. Proc. Plant Sci. 1980, 89, $185-191$.

68. Paoletti, M.; Seymour, F.A.; Alcocer, M.J.C.; Kaur, N.; Calvo, A.M.; Archer, D.B.; Dyer, P.S. Mating type and the genetic basis of self-fertility in the model fungus Aspergillus nidulans. Curr. Biol. 2007, 17, 1384-1389. [CrossRef] [PubMed]

69. Baidya, S.; Cary, J.W.; Grayburn, W.S.; Calvo, A.M. Role of nitric oxide and flavohemoglobin homolog genes in Aspergillus nidulans sexual development and mycotoxin production. Appl. Environ. Microbiol. 2011, 77, 5524-5528. [CrossRef] [PubMed]

70. De Souza, C.P.; Hashmi, S.B.; Osmani, A.H.; Andrews, P.; Ringelberg, C.S.; Dunlap, J.C.; Osmani, S.A. Functional Analysis of the Aspergillus nidulans Kinome. PLoS ONE 2013, 8, e58008. [CrossRef] [PubMed]

71. Xiang, X.; Osmani, A.H.; Osmani, S.A.; Xin, M.; Morris, N.R. NudF, a nuclear migration gene in Aspergillus nidulans, is similar to the human LIS-1 gene required for neuronal migration. Mol. Biol. Cell 1995, 6, $297-310$. [CrossRef] [PubMed]

72. Bayram, O.; Biesemann, C.; Krappmann, S.; Galland, P.; Braus, G.H. More than a repair enzyme: Aspergillus nidulans photolyase-like CryA is a regulator of sexual development. Mol. Biol. Cell 2008, 19, 3254-3262. [CrossRef] [PubMed]

73. Kawasaki, L.; Sánchez, O.; Shiozaki, K.; Aguirre, J. SakA MAP kinase is involved in stress signal transduction, sexual development and spore viability in Aspergillus nidulans. Mol. Microbiol. 2002, 45, 1153-1163. [CrossRef] [PubMed]

74. Semighini, C.P.; Harris, S.D. Regulation of apical dominance in Aspergillus nidulans hyphae by reactive oxygen species. Genetics 2008, 179, 1919-1932. [CrossRef] [PubMed]

75. Westfall, P.J.; Momany, M. Aspergillus nidulans septin AspB plays pre- and postmitotic roles in septum, branch, and conidiophore development. Mol. Biol. Cell 2002, 13, 110-118. [CrossRef] [PubMed]

76. Hernández-Rodríguez, Y.; Hastings, S.; Momany, M. The septin AspB in Aspergillus nidulans forms bars and filaments and plays roles in growth emergence and conidiation. Eukaryot Cell 2012, 11, 3112-3113. [CrossRef] [PubMed]

77. Busch, S.; Eckert, S.E.; Krappmann, S.; Braus, G.H. The COP9 signalosome is an essential regulator of development in the filamentous fungus Aspergillus nidulans. Mol. Microbiol. 2003, 49, 717-730. [CrossRef] [PubMed]

78. Busch, S.; Schwier, E.U.; Nahlik, K.; Bayram, O.; Helmstaedt, K.; Draht, O.W.; Krappmann, S.; Valerius, O.; Lipscomb, W.N.; Braus, G.H. An eight-subunit COP9 signalosome with an intact JAMM motif is required for fungal fruit body formation. Proc. Natl. Acad. Sci. USA 2007, 104, 8089-8094. [CrossRef] [PubMed]

79. Bok, J.W.; Keller, N.P. LaeA, a regulator of secondary metabolism in Aspergillus spp. Eukaryot Cell 2004, 3, 5273-5275. [CrossRef]

80. Bayram, O.; Krappmann, S.; Ni, M.; Bok, J.W.; Helmstaedt, K.; Valerius, O.; Braus-Stromeyer, S.; Kwon, N.J.; Keller, N.P.; Yu, J.H.; et al. VelB/VeA/LaeA complex coordinates light signal with fungal development and secondary metabolism. Science 2008, 320, 1504-1506. [CrossRef] [PubMed] 
81. Sarikaya, B.O.; Bayram, O.; Valerius, O.; Park, H.S.; Irniger, S.; Gerke, J.; Ni, M.; Han, K.H.; Yu, J.H.; Braus, G.H. LaeA control of velvet family regulatory proteins for light-dependent development and fungal cell-type specificity. PLoS Genet. 2010, 6, e1001226. [CrossRef] [PubMed]

82. Bayram, O.; Braus, G.H. Coordination of secondary metabolism and development in fungi: The velvet family of regulatory proteins. FEMS Microbiol. Rev. 2012, 36, 12-14. [CrossRef] [PubMed]

83. Patananan, A.N.; Palmer, J.M.; Garvey, G.S.; Keller, N.P.; Clarke, S.G. A novel automethylation reaction in the Aspergillus nidulans LaeA protein generates S-methylmethionine. J. Biol. Chem. 2013, 288, 14032-14045. [CrossRef] [PubMed]

84. Nitsche, B.M.; Jørgensen, T.R.; Akeroyd, M.; Meyer, V.; Ram, A.F. The carbon starvation response of Aspergillus niger during submerged cultivation: Insights from the transcriptome and secretome. BMC Genomics 2012, 13, 380. [CrossRef] [PubMed]

85. Jørgensen, T.R.; Nitsche, B.M.; Lamers, G.E.; Arentshorst, M.; van den Hondel, C.A.; Ram, A.F. Transcriptomic insights into the physiology of Aspergillus niger approaching a specific growth rate of zero. Appl. Environ. Microbiol. 2010, 76, 5344-5355. [CrossRef] [PubMed]

86. Van Leeuwen, M.R.; Krijgsheld, P.; Bleichrodt, R.; Menke, H.; Stam, H.; Stark, J.; Wösten, H.A.; Dijksterhuis, J. Germination of conidia of Aspergillus niger is accompanied by major changes in RNA profiles. Stud. Mycol. 2013, 74, 59-70. [CrossRef] [PubMed]

87. Fu, C.; Iyer, P.; Herkal, A.; Abdullah, J.; Stout, A.; Free, S.J. Identification and characterization of genes required for cell-to-cell fusion in Neurospora crassa. Eukaryot Cell. 2011, 10, 1100-1109. [CrossRef] [PubMed]

88. Wada, R.; Jin, F.J.; Koyama, Y.; Maruyama, J.; Kitamoto, K. Efficient formation of heterokaryotic sclerotia in the filamentous fungus Aspergillus oryzae. Appl. Microbiol. Biotechnol. 2014, 98, 3253-3254. [CrossRef] [PubMed]

89. Carlile, M.J. The Success of the Hypha and Mycelium. In The Growing Fungus; Gow, N.A.R., Gadd, G.M., Eds.; Chapman and Hall: London, UK, 1995; pp. 3-19.

90. Teutschbein, J.; Albrecht, D.; Pötsch, M.; Guthke, R.; Aimanianda, V.; Clavaud, C.; Latgé, J.P.; Brakhage, A.A.; Kniemeyer, O. Proteome profiling and functional classification of intracellular proteins from conidia of the human-pathogenic mold Aspergillus fumigatus. J. Proteome Res. 2010, 9, 3427-3442. [CrossRef] [PubMed]

91. Albrecht, D.; Guthke, R.; Brakhage, A.A.; Kniemeyer, O. Integrative analysis of the heat shock response in Aspergillus fumigatus. BMC Genom. 2010, 11, 32. [CrossRef] [PubMed]

92. Tsitsigiannis, D.I.; Zarnowski, R.; Keller, N.P. The lipid body protein, PpoA, coordinates sexual and asexual sporulation in Aspergillus nidulans. J. Biol. Chem. 2004, 279, 11344-11353. [CrossRef] [PubMed]

93. Duarte, M.; Peters, M.; Schulte, U.; Videira, A. The internal alternative NADH dehydrogenase of Neurospora crassa mitochondria. Biochem. J. 2003, 371, 1005-1011. [CrossRef] [PubMed]

94. Tsai, H.F.; Wheeler, M.H.; Chang, Y.C.; Kwon-Chung, K.J. A Developmentally Regulated Gene Cluster Involved in Conidial Pigment Biosynthesis in Aspergillus fumigatus. J. Bacteriol. 1999, 181, 6469-6477. [PubMed]

95. Tsai, H.F.; Washburn, R.G.; Chang, Y.C.; Kwon-Chung, K.J. Aspergillus fumigatus arp1 modulates conidial pigmentation and complement deposition. Mol. Microbiol. 1997, 26, 175-183. [CrossRef] [PubMed]

96. Tsai, H.F.; Fujii, I.; Watanabe, A.; Wheeler, M.H.; Chang, Y.C.; Yasuoka, Y.; Ebizuka, Y.; Kwon-Chung, K.J. Pentaketide melanin biosynthesis in Aspergillus fumigatus requires chain-length shortening of a heptaketide precursor. J. Biol. Chem. 2001, 276, 29292-29298. [CrossRef] [PubMed]

97. Langfelder, K.; Jahn, B.; Gehringer, H.; Schmidt, A.; Wanner, G.; Brakhage, A.A. Identification of a polyketide synthase gene (pksP) of Aspergillus fumigatus involved in conidial pigment biosynthesis and virulence. Med. Microbiol. Immunol. 1998, 187, 798-799. [CrossRef]

98. Jackson, J.C.; Higgins, L.A.; Lin, X. Conidiation color mutants of Aspergillus fumigatus are highly pathogenic to the heterologous insect host Galleria mellonella. PLoS ONE 2009, 4, e4224. [CrossRef] [PubMed]

99. Muñoz-Adalia, E.J.; Fernández, M.M.; Diez, J.J. The use of mycoviruses in the control of forest diseases. Biocontrol. Sci. Technol. 2016, 26, 577-604. [CrossRef]

(C) 2018 by the authors. Licensee MDPI, Basel, Switzerland. This article is an open access article distributed under the terms and conditions of the Creative Commons Attribution (CC BY) license (http:/ / creativecommons.org/licenses/by/4.0/). 